\title{
Alternative Facts in Musicology and Vechnaya Pamyat' in Shostakovich's Symphony No. 5
}

\section{Eileen Mah}

The idea of "alternative facts" gained attention in national politics after the 2016 presidential election, and continued with perhaps unprecedented pervasiveness and gravity at the end of that presidential term, but it is unfortunately not a new phenomenon. An alternative fact is a special kind of lie, one that is deliberately and maybe even obviously false, but presented as truth, and that also incorporates purposeful distraction from the issue, for example, by creating the perception of adversarial relationship or even victimization by adversaries, and/or by insulting and discrediting those people.

Perhaps more important is when an alternative fact becomes a widely accepted truth. The mechanisms for this include sustained repetition of the alternative facts from people with the highest levels of visibility and power, backed up through the fallacy of confirmation bias: making a claim (which could be an alternative fact) and then setting out to gather evidence, fabricate evidence, or interpret evidence in a biased way to "prove" the claim. This could certainly involve use of half-truths, or cherry-picking of convenient portions of truth. Also related is the psychologically explained phenomenon of belief persistencemaintaining stubborn belief in the truth of something even (long) after it has been thoroughly debated, debunked, or rebuked (or maintaining stubborn disbelief of obvious facts).

Alternative facts, half-truths, confirmation bias, and belief persistence are well studied in fields such as psychology, sociology, and political science, but they have not necessarily been applied to academia itself, or other particular fields, including musicology. These phenomena, though, can all manifest themselves in teaching as well as in the research of both students and professionals, with motivations ranging from political propaganda to personal agenda, nefarious or not. Without risking more fallacies by speculating about intentions, the nevertheless observable consequences deserve a moment of attention and analysis, particularly in the current historical moment when the consequences in the political and societal realm feel quite dire, regardless of whether the phenomenon or its severity are really unprecedented. Alternative facts or claims based on confirmation bias can end up as accepted truths, or unquestioned and Current Musicology 108 (Spring 2021)

()2021 Mah. This is an open access article distributed under the terms of the Creative Commons-Attribution-Non-CommercialNoDerivatives License (CC BY-NC-ND). 


\section{Current Musicology}

commonly perpetuated myths, often in published works or in widely disseminated media. From the hermeneutical perspective in musicology, when rational discussion of polarized truths turns into abusive argument, or when the truth seems to reside in an inaccessibly gray area between the poles, the real consequence is cynical apathy, and therefrom, a lack of analysis or interpretation, and a shifting of attention to the offensiveness and defensiveness of the analyzers, rather than on the music. Another consequence can be equivocation for lack of "concrete" or literal proof (such as a note from the composer explaining exact intentions or motivations), even if in retrospect these sorts of hesitancies might seem absurd.

Two notorious examples are the musicological "wars" concerning Tchaikovsky's Symphony No. 6 and Shostakovich's Symphony No. 5. Both these pieces have been hashed over countless times, and they are both regularly found in music history and music appreciation classes, as well as in orchestra programming and recording, and on streaming and broadcast media. Very often these pieces are accompanied by some version of their popular but debated interpretations-Tchaikovsky's symphony as evidence of his suicide and its relation to his gayness, and Shostakovich's symphony as evidence of his dissidence (or covert dissidence) against Stalin. The persistent interpretation/description (in orchestra program notes, radio blurbs, music appreciation/history classrooms, etc.) of Shostakovich's Fifth usually points out the "grotesque" march of the first movement, the "satiric" dance of the second movement, the "lament" of the third movement, and the "forced happy ending" of the finale.

All authors writing on Shostakovich's Fifth for the general public seem to reference the general circumstances of Stalinist Soviet Union; most authors mention something about ambiguity of meaning and even hint at the presence of irony, but avoid vocabulary such as "protest" or "dissident," and prefer unspecific language to describe the music. Phillip Huscher, for instance, writing program notes for the Chicago Symphony in 2017, writes of the third movement that "every phrase carries meaning, and we hang on each note," but he does not really say what the meanings are. He acknowledges controversy over what they are ("Separating fact from fiction is no mere pastime in discussing Soviet music"), and concludes that "in the end, the music must speak for itself." In the end, however, Huscher does not really let the music speak for itself. He fully describes, but only vaguely interprets, the music-for example, that the third movement is "troubled," and crucially, about the "happy ending" of the finale, though he does venture to say that "it is somehow forced," he ascribes this not to 
musical evidence, but only to "our hindsight-our knowledge of the undeniable sorrow and despair of Shostakovich's last works" (29-31).

Pauline Fairclough, in the latest biography of Shostakovich from 2019, more or less declares her intent not to participate in the "Shostakovich Wars," but she still details various persistently popular Shostakovich myths and images as they exist in the United Kingdom (7-12). Likewise, the articles by Richard Taruskin and others mentioned in this paper are not exactly current any more, but nevertheless, the polarized assertions of the war are still very much in circulation. As I am perusing YouTube comment sections under videos of Shostakovich's music, the "war" is absolutely still happening, in $2021 .{ }^{1}$ The important thing to point out about this is that it is not, for instance, Richard Taruskin, Laurel Fay, Solomon Volkov, or Dmitry Feofanov making snarky comments on YouTube; the snarky war is very much in the common, public sphere, with all the tactics, language, and alternative facts of the "original" war in the academic sphere.

The debate in the academic and popular spheres alike includes many valid and convincing points, and also no shortage of abusive and adversarial behavior on both (or all) sides, ironically, even as the writers expose precisely the practice of manipulative rhetoric, within the context of the debate as well as in the historical context of these works. Taruskin's basic argument (1997 and 2009) is against overly specific or overly simplistic "definitive" readings; he repeatedly explains the fallacy of confirmation-bias, the fallacy that meaning received proves meaning intended, and the fallacy of biographical interpretation. Taruskin also makes refutations to the various alternative facts-his term is "public lies" (1997, 511 ff.) —and pigeon-holing portrayals of Shostakovich made by everyone from Soviet officials in Shostakovich's time to current musicologists, revealing belief persistence, or what he calls cultish and even jihad-ish behavior (2009, 16-17). He goes so far as to liken the methods of other musicologists to the very methods of Stalin $(1997,542)$.

Sidestepping the endless details of the argument (and of the abuse, and of the self-vindications regarding accusations of abuse), there are several places where the argument seems to have gotten in the way of fully analyzing the music. One problem in interpreting Shostakovich is how much to read into his works, and what biographical conclusions, if any, to draw from them; this problem must be grappled with, since Shostakovich is unique in long being claimed by both official Soviet culture and dissident culture. In both cases, the readings tend to be single-planed. David Fanning, editor of the volume (1995) in which Taruskin's chapter "Public Lies and Unspeakable Truths" first appeared, 


\section{Current Musicology}

acknowledges the many challenges of interpreting Shostakovich's text, subtext, tone, and historical/biographical context. However, he also strongly cautions that "to duck the question of interpretation altogether is not the answer [emphasis mine] [...] If there is evidence for a specific representationalist interpretation, better that it should be presented [...] and argued over, as I trust it will be" (2001, 139).

A number of authors in the 2000s have offered analyses that strike a balance between (or among) the various prominent-and polarized-sides of Shostakovich interpretation. In an example of how all this has been filtered out by more emerging scholars, a 2011 thesis by Anna Megan Davis summarizes many previous summaries of the Shostakovich War (or "Question"), clearly echoing some of Taruskin's thoughts on the essential roles of ambiguity, ambivalence, and multiplicity of interpretations in Shostakovich's music, "understanding it as at least in part intentional [...] and a defining characteristic" (15). What I would like to add and stress, is that ambiguity and ambivalence can involve particularities, and multiplicity of interpretation does not preclude specificity of interpretation. Purposely making something ambiguous is also arguably a quite specific choice on the part of the composer, and thus also merits specificity of interpretation.

The particular case of Shostakovich's Symphony No. 5 serves to illustrate perfectly the simultaneous presence in his music of both introversive and extroversive meaning in the same musical gestures, including simultaneous specificity and abstraction of meaning. The possibility for these to function at the same time in the same piece is crucial for understanding the many levels of Shostakovich's symphony, and perhaps an essential part of interpreting even his most scrutinized works. I also am not interested in antagonizing anyone or participating in any wars; I just want to build on one of Taruskin's typically insightful observations about Shostakovich's possible source materials to show how the composer, in fusing a neoclassical symphonic paradigm of abstract musical structures with specifically meaningful references, Shostakovich may have manipulated his musical materials into his own species of alternative fact: he made his music beyond suspicion of containing dissident meaning and beyond suspicion of not containing dissident meaning, and either one could be proved or disproved. A truly total view may be impossible, but this does not mean, however, that the listener is excused from considering what it means to prove something in musical interpretation, or which proof has the stronger case, or, proofs aside, why the composer structured his piece in an ambiguous waywhich might reveal a truth in itself. 
Another academic war-a related one, and one that has possibly been simmering for centuries-also includes the issue of the descriptive vs. the interpretive, or as Hans Gumbrecht calls it, presence vs. meaning (2004). Authors such as the late Susan Sontag (1966), or more currently, Carolyn Abbate (2004 and 2017, for example) -with particular emphasis on the ephemeral nature of musical experience-have taken positions firmly against interpretation. Gumbrecht mostly takes great pains to convey a reconciliatory tone and present nuanced perspectives and a long historical view on the sometimes highly polarized and antagonistic argument. Again, one contention is about who (if anyone) has the greater claim to truth, reality, importance, and necessity. Included in the polemic are complaints that the other side is making exclusive claims to these things, and in vocabulary that again suggests victimization (attack, intimidation, usurp, resistance, liberation, prevail), and with potentially insulting accusations (of various things, from triviality to arrogance). Gumbrecht, though, while making his plea for greater attention to "presence," notably acknowledges that "presence and meaning always appear together [...] and are always in tension" $(2004,105)$.

The broader context as well as the smaller details of this issue and how I would tie them to semiotics, literate traditions, and oral traditions in Western music have to be the subject of a separate paper, but for the present discussion, a few aspects need inclusion. Specifically in the field of music, authors such as Karol Berger (2005) and Julian Horton (2020) have, like Gumbrecht, argued for the inseparability of surface and content, and the impossibility of pure, unmediated experience, completely free of interpretation-though unlike Gumbrecht, for the purpose of championing interpretation. Music is sonic and happens through real time, and thus is ephemeral in nature, but this does not mean that it therefore lacks content and cannot be interpreted. Jonathan Bellman further explains how the inclination to mystify music as belonging "in some magical meta-realm lying beyond meaningful discussion" is particularly unhelpful in the vast body of Western music that is filled with referential material - material whose meaning is very knowable (2017, 41-43 ff.).

That referential material often comes in the form of what have come to be known as musical "topics"-musical gestures that carry broadly recognizable associative meanings-as well as quotations from other music. Musical topics are among the most "present" of musical materials, as they are at the surface of music and rely on instant, aural recognition in their ephemeral presentation, so they seem more like things to be experienced rather than analyzed or interpreted. However, as referential material, they are thus a prime locus for the enmeshing 


\section{Current Musicology}

of experience and analysis. The caveat is that topical associations and quotational allusions can be culturally specific in both time and place, so they sometimes have to be learned and studied in order to simulate the original experience, thereby providing much opportunity for error, even if the cause is simply unwitting ignorance, and musical alternative facts can be created even if we think our approach is purely descriptive. Without diverging too much into this much larger discussion, suffice it here to say that these difficulties should not stop us from trying to understand, or embracing the connection, rather than the separation, of presence and meaning. Furthermore, in regard to musical topics, their formation, their reception/interpretation, and their evolving constellations of associations are all largely in the realm of oral transmission, rather than in the vaunted literate tradition so tied to hermeneutics. Orally transmitted knowledge, though, is no less real, and no less important, and no less interpretable.

Berger has laid out categories for thinking about what could constitute "musical facts," as well as distinctions between establishing facts and interpreting facts (2005, 490-93). The meaning of an isolated, individual fact, or in music, an isolated, individual musical gesture-is vastly different from the meaning of a collection of facts or gestures. This is actually one of the core ideas of topic theory in music - that the meaningful semiotic codes in music (musical topics) are almost always a collection of musical gestures, and they have commonly shared cultural associations, rather than unique, individual associations. Individual composers, however, use musical topics in unique ways, and this is where interpretation really enters. Musical gestures themselves are by definition an organization of various musical elements, and they are arguably facts in that they are there (whether in performance or in notation); they are present, and their presence is not coincidental or random. Describing musical gestures establishes them as such facts, but merely describing or acknowledging their presence is no substitute for analyzing why they are there. The act of description can itself, of course, contain interpretation, and interpreters can also run the risk of what Taruskin disparages as tautological, verificationist "proofs" that are internally consistent but otherwise absurd $(1997,539)$.

Before fully delving into Shostakovich, a few observations on the main point of contention about Tchaikovsky's symphony will further explicate the perils of under-analysis, or describing but not interpreting, perhaps because of polarized argument. The symphony has been read autobiographically, and in particular, as intended by Tchaikovsky to be about his gayness and/or as his "suicide note," since he died within days of its premiere. The suicide theory was put forth in 1980 (1981 in English) by Aleksandra Orlova, and was included in 
the 1980 edition of the Grove Dictionary of Music, and is still mentioned (though now called "rank speculation") by Roland John Wiley in the current Grove Music Online, and also in many a non-scholarly article such as Wikipedia, program notes, newspaper concert reviews, etc. (Keller 2019 or May 2018, for example). A lengthy audio blog on Classic FM (classical music radio station in the United Kingdom), essentially fully concludes that the suicide theory is true, though carefully adding in the last moments that "the frustrating truth is that we'll probably never know" (Lihoreau 2018). The most scholarly location for the homosexual reading of the symphony is by Timothy Jackson in the Cambridge Music Handbooks series from 1999 (39 ff.), so it has a wide and still current circulation.

The point of mentioning all this is that both the homosexual and suicide readings, however much debated or rebuked, are nevertheless persistent and widespread. Furthermore, in the process of trying to separate fact from fiction, babies get thrown out with the bathwater. For example, Taruskin, in his thorough and vigorous discrediting of the symphony as a "homosexual tragedy," says that "the exuberant and exhilarating third movement is usually the main obstacle to the construction of a consistent metanarrative of the kind that Jackson is so determined to 'reveal'," and also that this movement "has to be sedulously ignored by those who want to read the symphony as a suicide note" (2009, 133-35). Aside from the questionability of including the word "usually" (in "the third movement is usually the main obstacle"), Taruskin does not say why this happy movement cannot fit in a tragic metanarrative; on the contrary, it would seem to increase the tragedy and the drama of the tragedy, because it comes out of order, being the third movement rather than the finale, and the actual slow, despairing finale is objectively unconventional.

Taruskin acknowledges the finale as well as its undisputed character, but he does not interpret the abnormal ordering of movements. He says of Tchaikovsky's "ebullient" style that it "had its origins in a patriotic fervor" and was a reflection of "the stature lent him from on high" as "the uncrowned tsar of Russian music" (2009, 133). This may well be true of the ebullient third movement in the Sixth Symphony, but it does not explain why Tchaikovsky chose to include it in this symphony. Again, it does not disqualify it from being part of a tragic narrative, and we still need to interpret its position in the structure of the whole work. Whether the symphony was a suicide note or not, its ending is crushingly and unusually tragic.

As for the famous quintuple "waltz" of the second movement, Taruskin claims that it "also fits the commonplace conception of the symphony as record 


\section{Current Musicology}

of the composer's sufferings very badly: despite its $5 / 4$ meter, it comes off as yet another waltz, another vicarious offering to the imperial stage," similar to the many waltzes in the fifth symphony, Sleeping Beauty, and Nutcracker $(2009,133)$. Once more, why cannot something that sounds like a happy, graceful waltz be part-a disquieting part—of a tragic narrative? And should we not interpret the choice of quintuple meter? Should we not interpret the middle movements in the context of the whole symphony? In a different book (Defining Russia), Taruskin speaks of the meter in this movement simply as a distinctively Russian rhythmic feature $(1997,31)$. It may well be, but still, the question remains of why he would use it here, and why in combination with otherwise clearly waltzy music.

Similarly, Taruskin acknowledges the reference in the first movement to the Russian Orthodox requiem and cautions against interpreting it as suicide note, but again does not venture to explain why else Tchaikovsky included a reference to death and memorial if he did not in fact intend to make a reference to death and memorial $(2009,133)$. This symphony may not have been explicitly programmatic (the subtitle "Pathétique" having been added after the premiere), but this in no way means that it is devoid of meaning or program. Taruskin's main concern here seems to be the problem of interpreting an autobiographical metanarrative, but his reasoning based on musical evidence is not convincing, and somehow, at least in these published writings, it sounds like he does not think the symphony is tragic at all. The current Grove article by Wiley on Tchaikovsky rejects autobiographical interpretation while still acknowledging the sad, funereal quality, but also completely omits the issue of the last movement and the ordering of the movements.

As with Tchaikovsky's Sixth, polarizing argument over various readings of Shostakovich's Fifth sometimes ends in having no interpretation at all. Concerning Ian McDonald's reading of a section from the first movement, Taruskin spends much energy mocking McDonald's imposed narrative as "trivializing" - and maybe rightfully, as McDonald fancifully describes a detailed cinematic scene with specific instruments and musical themes assigned to specific characters and actions, and even imagined dialogue. He spends more energy insulting McDonald for using non-transposed pitches to describe the horn part, implying that McDonald is incompetent or ignorant because of this (1997, 539 and also 2009, 20). What is missing is Taruskin's interpretation of the passage, though he has certainly interpreted many other passages, and the symphony as a whole, in considerable detail.

At times, Taruskin casts doubt on the possibility of interpreting Shostakovich at all. He goes so far as to say about him that "the impulse to 
communicate urgently in an atmosphere of threat did lead, at times, to an overreliance on extroversive reference as a bearer of essential meaning, and a correspondingly debased level of musical discourse" (1995, 55). Though Taruskin did edit this part out of the revised version of the article (in Defining Russia Musically, 1997), in his discussion from 2009 of the Fifth Symphony, he notes its saturation with musical topics, but ignores the range of allusive specificity topics can have, downplaying their significance altogether because of what he calls their transferability-in other words, that anyone can interpret topics in any way, and therefore, rather than making content more explicit, they limit it to any number of overly specific readings. Taruskin also comments in this same passage that "in actual practice they [topics] easily lead to a Bakhtinian 'carnivalism,' especially when they are as brusquely contrasted, or violently exaggerated, as they often are in Shostakovich" $(2009,306)$. The Bakhtinian carnivalesque has to do with alteration and even upending of social norms within the ritualistic masked carnival; indeed, the contrasts are brusque and the masked identities are exaggerated. What I would like to add about the carnivalesque (and therefore about topics) is that these masks and the otherwise impermissible actions or social interactions resulting therefrom absolutely rely on specific and recognizable types (be they archetypes or stereotypes) - exactly in the same way that musical topics and their interaction with each other operate. Given Shostakovich's general circumstances of negotiating survival in Soviet Russia, the carnivalesque act of otherwise impermissible truth-telling could at any moment be present under a mask-and one that most likely has multiple, even contradictory, identities or functions. That multiplicity does not diminish the specific importance of any one of those identities, and is an important, specific trait in itself.

At other times, Taruskin seems conflicted about how to interpret Shostakovich. He continually rails against definitive or biographical readings of Shostakovich, and above all, against calling him a dissident. He says that this "locks the music in the past" and that it is better to "let it remain supple, adaptable, ready to serve the future's needs." Taruskin quickly adds, though, that "anyone [...] alive to the issues his [Shostakovich's] work so dramatically embodies will listen to it (pace Virgil Thomson) without mind-wandering, unless musical perceptions are wholly divorced from moral perceptions" (497). He also argues for the necessity of interpreting the Fifth, the inseparability of the introversive and the extroversive, and how the symphony "self-evidently belongs to the tradition established in the wake of Beethoven's Ninth, whereby the music unfolds a series of symbols, gestures, or events that are immediately recognizable 


\section{Current Musicology}

as signs or symbols," and as clearly "a richly coded utterance, but one whose meaning can never be wholly encompassed or definitively paraphrased"-which is what saved Shostakovich (519-21).

Taruskin's main concern seems to center on his insistence that the designation of "dissident" for Shostakovich is an inaccurate, anachronistic, and romanticized stereotype-an alternative fact, we could say-but the other terms he uses to describe Shostakovich place him very much on the dissident side of tendencies at least: Shostakovich's Quartet No. 8 as a "note in a bottle"; Shostakovich's "heroic risk taking," and Shostakovich as a "civic artist" who "managed to bear witness against the state on behalf of the citizenry [...] composer and audience acted in collusion against authority" (1997, 493, 496). No one work, including the Fifth Symphony, should be taken to represent the entirety of the composer's output or singly used to argue for any biographical assertions. The Fifth Symphony, however, due to the circumstances of its composition-Shostakovich under threat of (more) condemnation by the regime-is a central piece in the dissidence argument.

Despite his warnings about interpreting allusive references in general, Taruskin, in discussing the Fifth Symphony, identifies a "near citation" in the third movement of a specific hymn from the Orthodox requiem, and therefrom draws specific interpretations about the agony and grief it represents, specific to the time and place of the composition. His evidence is music in the third movement about which he says: "the imitation is so literal that you can almost hear the string instruments intone the vechnaya pamyat'." Given the scoring, texture, and melodic contours of this movement, it is not a stretch to call this passage (which first appears at the very beginning of the movement and in various forms throughout the movement) as reminiscent of this hymn, or at least of Orthodox chant in general, and there is little disagreement about that; Taruskin also provides the larger context of placing Shostakovich within a Russian composition tradition in which quotation from the Orthodox requiem was a defining attribute $(1997,530){ }^{2}$ Vechnaya pamyat' ("Memory Eternal") specifically is the final part of the Russian Orthodox requiem service, or panikhida. However, regardless of whether Taruskin meant "near citation" or "literal imitation," the passage (shown in Example 1) really is neither, so why or how he likened the passage specifically to Vechnaya pamyat' (shown in Example 2 ) is uncertain. Their general aura of slow, intoned chanting matches, but not their particular rhythms, or pitches (or pitch relationship, regardless of key or mode), or the length of the passage. 


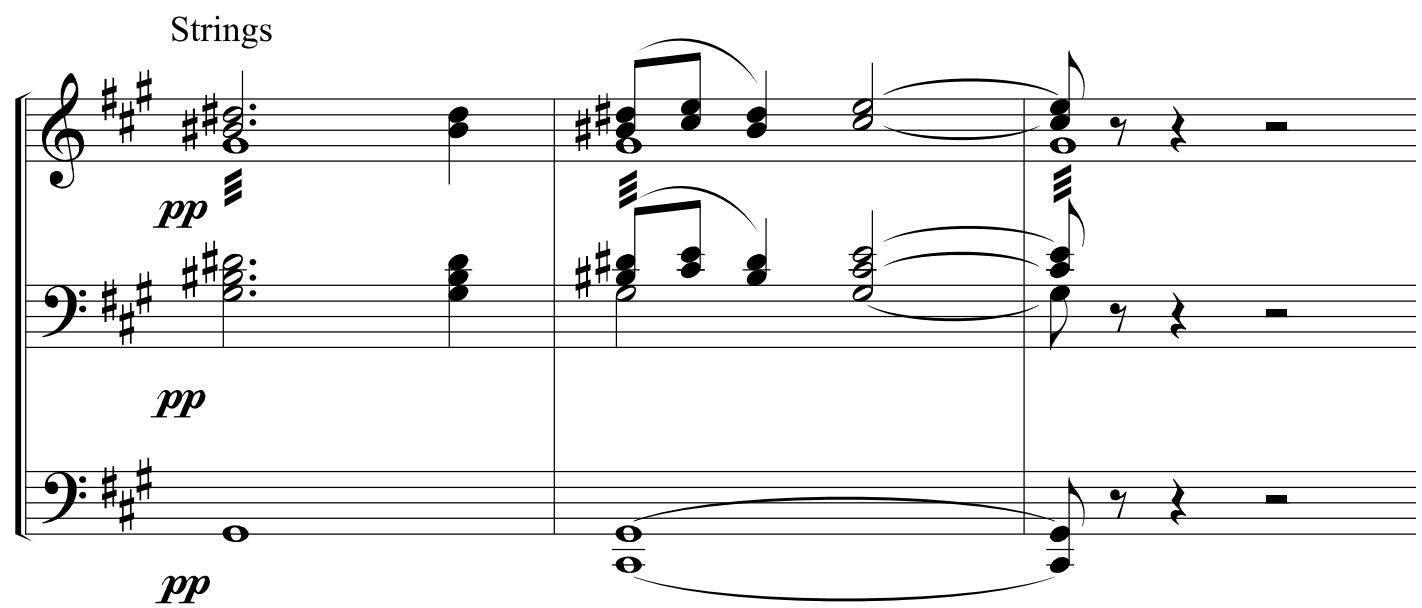

Example 1: Shostakovich, Symphony No. 5, Mvt. 3, Rehearsal 86.
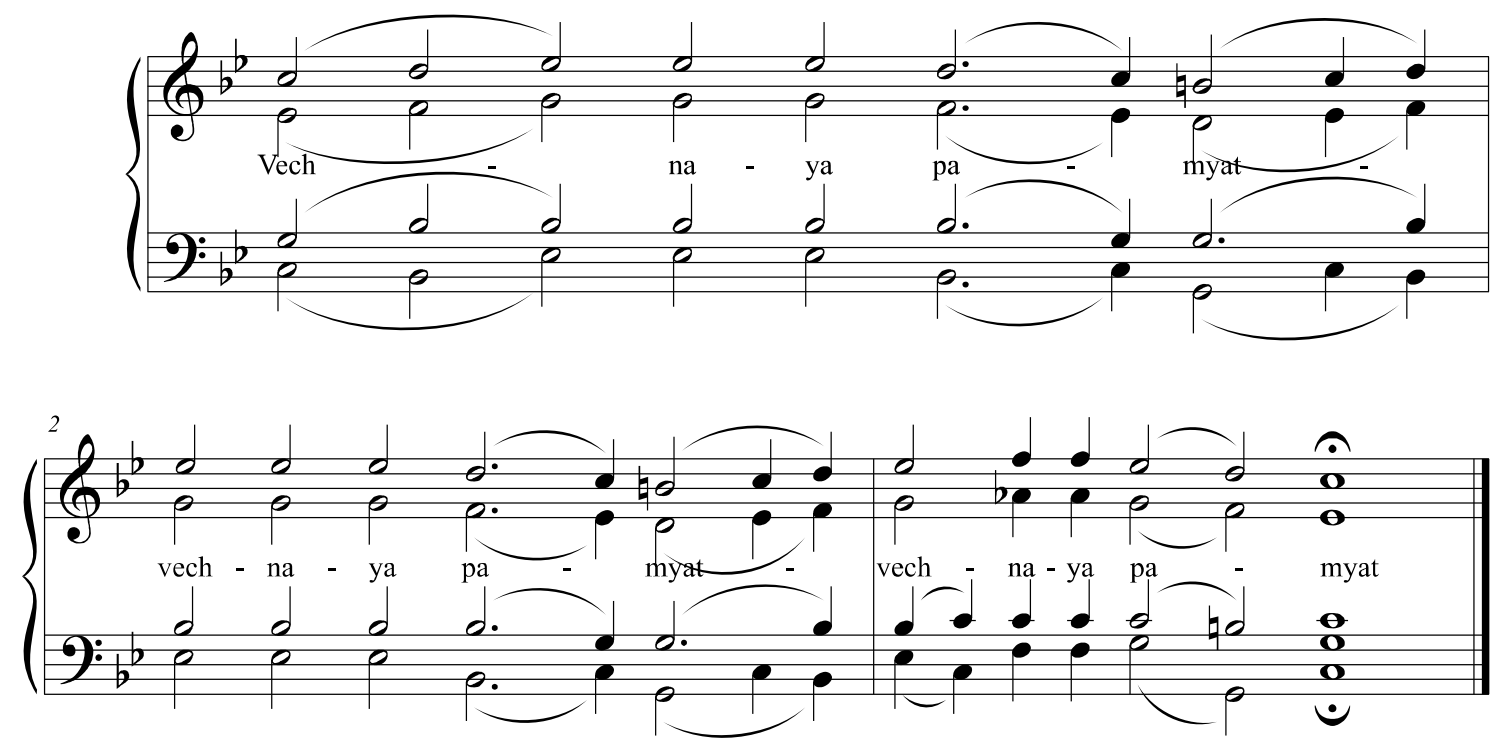

Example 2: Vechnaya pamyat', transcribed with clef changes for easier reading from Obikhod notnogo tserkovnogo peniya, ed. N. Bakhmetev, 1869. ${ }^{3}$

Taruskin is a prolific and widely-read author, whose words, on the one hand, will likely be immediately rejected by his detractors, or on the other hand, immediately accepted and then used repeatedly in subsequent research, such as the doctoral thesis by Davis (2011, 105-6). In that example, Davis presents the two musical examples side by side, just as Taruskin did, and Taruskin's original comparison-and thus the "presence" of Vechnaya pamyat' in the symphonymore or less becomes an alternative fact, whether through anyone's specific intention or not.

However, Taruskin's identification of the specific hymn Vechnaya pamyat' might be more important than dwelling on why it is a misidentification. Concerning the length of the fragment, it actually is important that Shostakovich does not quote the hymn in its entirety-likely dangerously unacceptable in the 


\section{Current Musicology}

atheistic era of Stalin. The exact melody and rhythms of Vechnaya pamyat', though, may possibly be truly quoted in motivic fragments, and not just present, but very present, throughout the entire symphony. As Taruskin points out, "Every member of the symphony's early audiences had lost friends and family members during the black year 1937, loved ones whose deaths they had to endure in numb horror," so Vechnaya pamyat' would be a fitting and poignant reference indeed $(1997,530)$. Note that the motifs of the hymn-identifying incipit shown in Example 3 also make up almost the entire melody:

A. The first part of the incipit is three ascending steps in equal, long note values; whole step-half step. This also closes the melody, in descending form.

B. Three repeated notes in equal, long note values.

C. Three steps, in both ascending and descending form; half step-whole step.
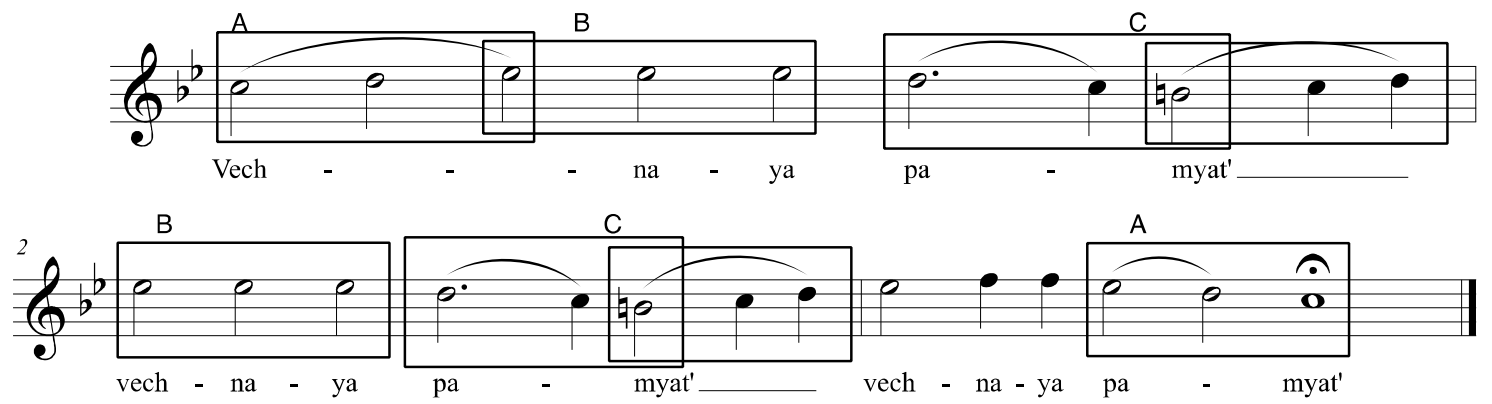

Example 3: Vechnaya pamyat', soprano (melody) part.

As an orchestral horn player, I noticed all these motifs through my analytical experience (or experiential analysis) of performing this symphony multiple times-before I even knew what Russian Orthodox music was, much less sounded like-and I first found them not in the third movement, but in the fourth, as shown in Example 4.

This passage occurs late in the movement, in the lead-up to the ending section, with low strings and horns taking turns iterating a three-note, stepwise ascent underneath a violin ostinato. I include the history of my personal process here as example of how my experience was also simultaneously analytical; I became acutely aware of this pattern of three ascending notes here because they were set apart and repeated, and then I realized this was not the first time.

I connected these three notes with the forceful and oft-repeated three-note stepwise ascent of the principal theme of the movement, shown in Example 5, and its inversion, shown in Example 6. 

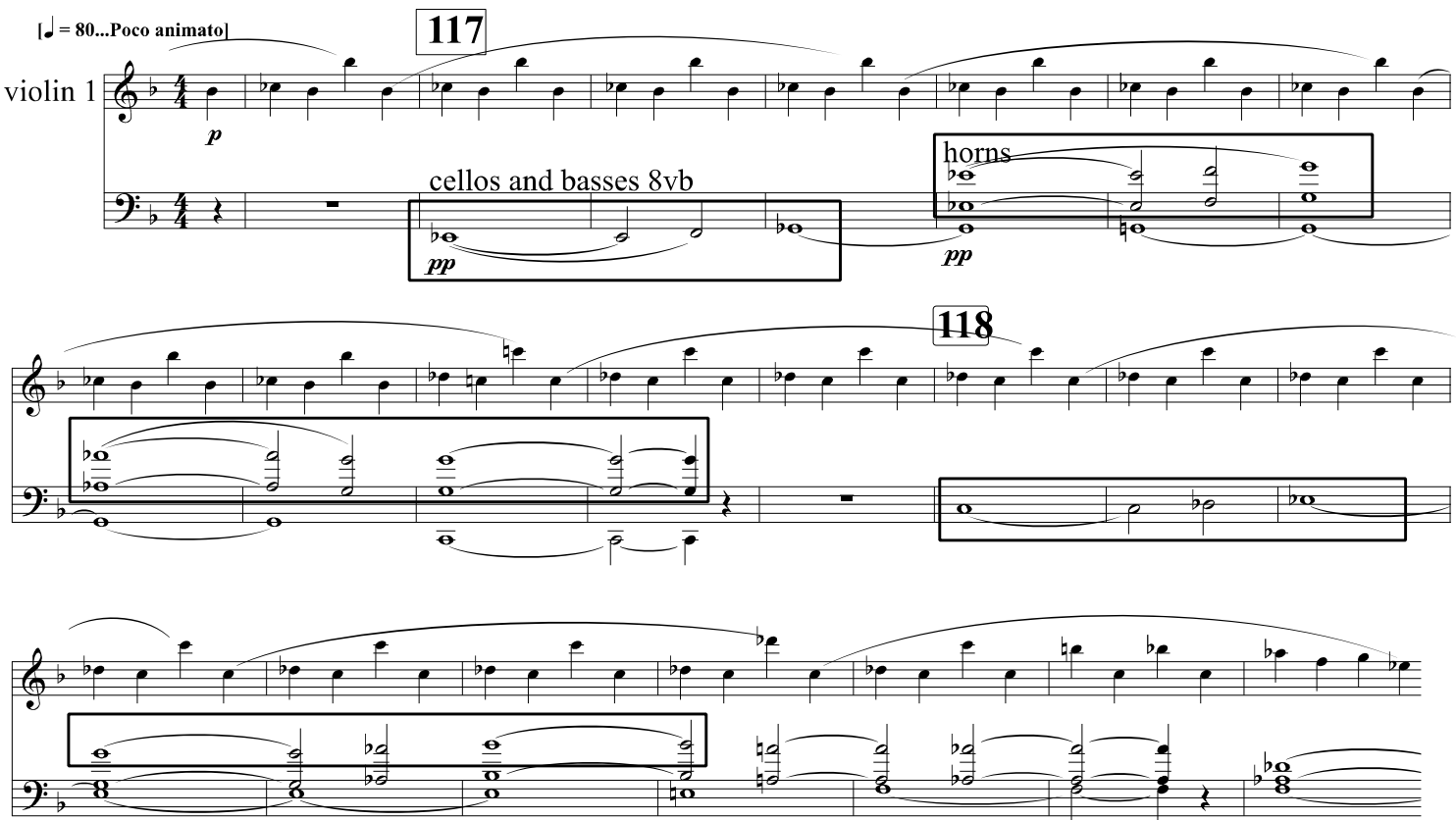

Example 4: Shostakovich, Symphony No. 5, Mvt. IV, 1 measure before Rehearsal 117.

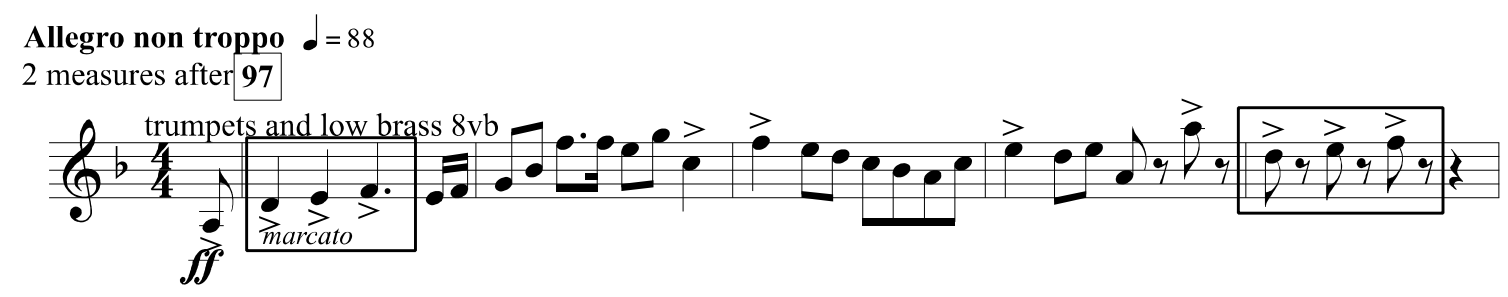

Example 5: Shostakovich, Symphony No. 5, Mvt. IV, 2 measures after Rehearsal 97. Principal theme of the movement (mm. 3-7).

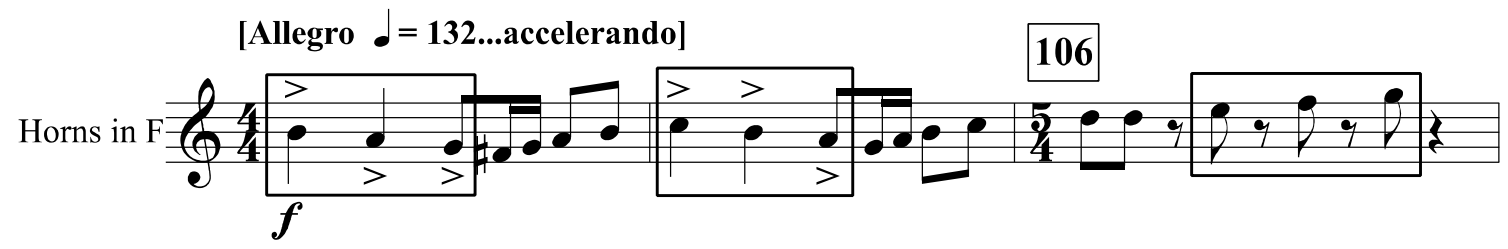

Example 6: Shostakovich, Symphony No. 5, Mvt. IV, 2 measures before Rehearsal 106.

Example 7 shows how the principal theme begins to be distilled down to the motif of the three ascending steps, in this very highlighted, grotesquely loud passage leading to a moment of crisis, i.e., an urgent and terrible climax, and one in which what will follow is not clear, either in technical harmonic terms or in the implied drama. After what is shown below, the tension builds for yet another two measures, culminating on a fully diminished chord, followed by silence; I cannot help but correlate this moment, and this type of moment, to the fully diminished crisis of m. 150 in the also extremely funereal second movement of Beethoven's Third Symphony. For me, that is a watershed moment in the transformation of the climaxes of eighteenth-century form into not just 


\section{Current Musicology}

climaxes, but the crises, of nineteenth-century form. The way Shostakovich does follow this moment of crisis is also reminiscent of Beethoven-to be discussed later, with examples of the repeated-note motif from Vechnaya pamyat'. In the larger issue of analyzing layers and sources of referential material in Shostakovich's symphony, but without veering too much into ShostakovichBeethoven analysis, suffice it to say that I am here adding to an already established endeavor. This includes the likening of the $\mathrm{D}$ minor/D major key scheme and the opening rhythmic motifs of Shostakovich's Fifth and Beethoven's Ninth (Tilson Thomas 2009, for example).

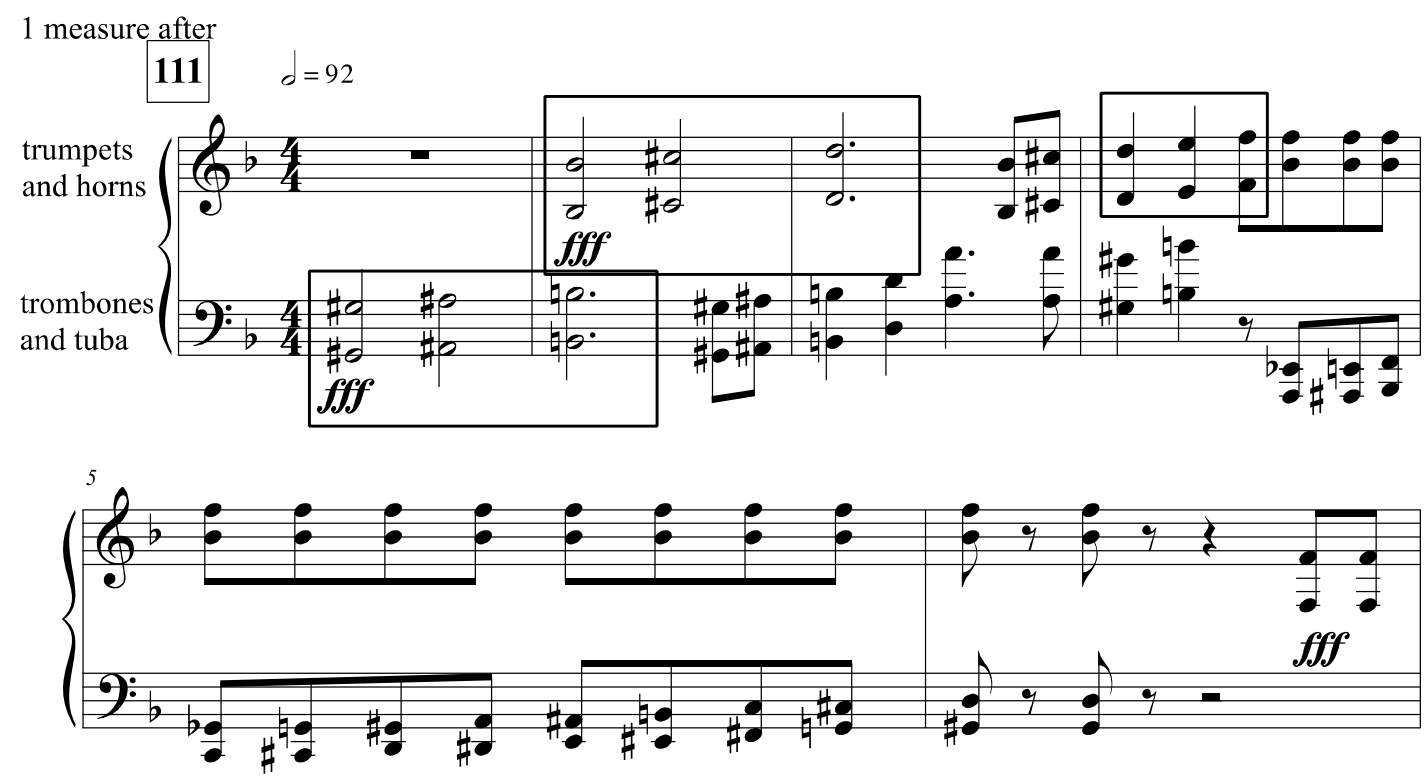

Example 7: Shostakovich, Symphony No. 5, Mvt. IV, 1 measure after Rehearsal 111.

Furthermore, and significantly, as the movement progresses to its end, the motif is again made prominent, first by the rhythmic augmentation and low, soft voicing (bassoons) of the principal theme in its recapitulation (five measures after reh. 121)-so that the three-note motif very much resembles the passage of Example 4 (reh. 117), in slow, long note values. This section sets up the gradual "triumphant" arrival of D major, as aptly described by Michael Tilson Thomas: "with a great deal of extra shoving and hauling [reh. 129-131], we make it to D major, but the process is painful and difficult" (2009). By the end of the movement, the three-note, ascending motif is all that remains of the theme, shown in Example 8: 


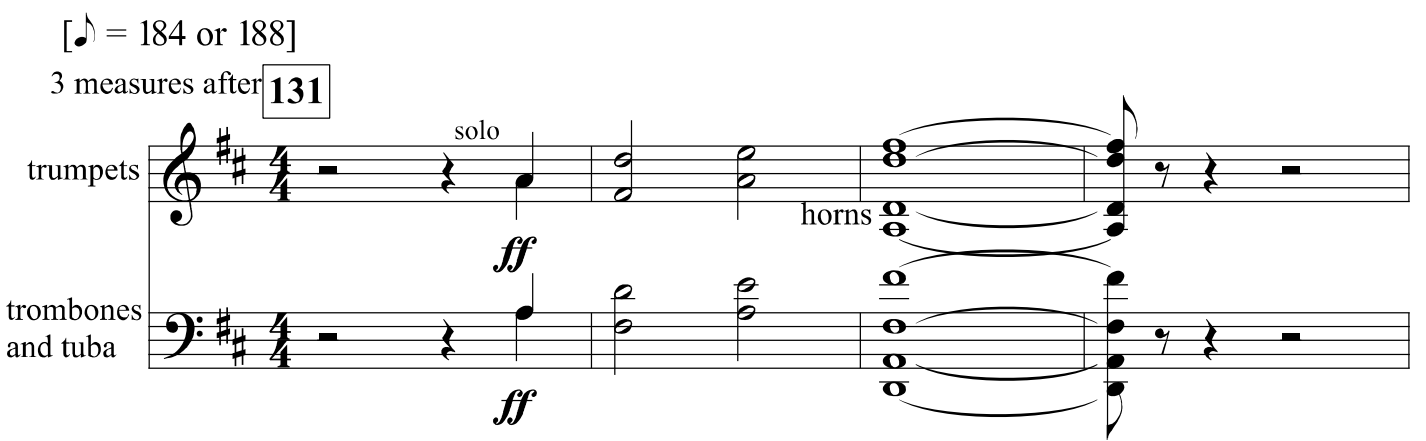

Example 8: Shostakovich, Symphony No. 5, Mvt. IV, 3 measures after Rehearsal 131.

Notably, of course, all these presentations of the motif vary as to the intervals between the three pitches-the whole step-half step, minor mode version; the half step-whole step version; and the whole step-whole step, major mode version, in blazing presentation by trumpets and trombones at the end of the symphony. I always wondered why the final melodic gesture (played by the same instruments) turned this ascending, D major arrival almost immediately to the version with the flatted middle note, and descending (shown in Example 9)$\mathrm{D}$ minor melody notes in a $\mathrm{D}$ major harmonic context.

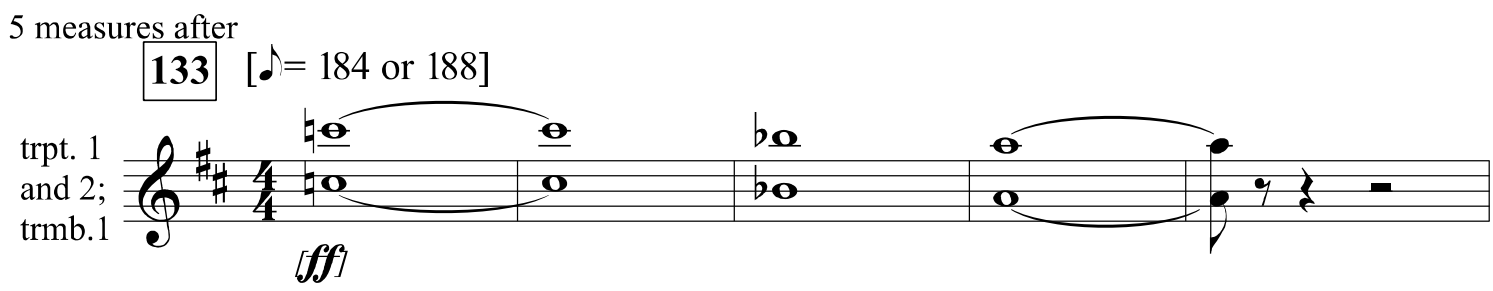

Example 9: Shostakovich, Symphony No. 5, Mvt. IV, 5 measures after Rehearsal 133.

At the time, I did not analyze beyond these observations, but I did know that ever since I first played a band transcription of the fourth movement of this symphony in high school (i.e., before I knew anything about anything), and then even more so when later (still knowing very little about very few things) I played the full, orchestral original, Shostakovich's Fifth Symphony was the first piece of music that ever terrified me.

Taruskin very nicely highlights the "suppression of the brass instruments" in the third movement, i.e., they are absent altogether, and he takes this as ironic, given what he has observed as the "obligatory lugubrious brass quintet" at secular Soviet funerals. Whether or not this was true in the 1930s as well, Taruskin goes on to analyze multiple ways that the entire movement evokes mourning and funeral, and specifically, the Russian Orthodox panikhida (1997, 530). Also, and notably, the three-note ascending and descending motifs from Vechnaya pamyat', though not identifiable in the passage Taruskin uses, do appear in 


\section{Current Musicology}

multiple other locations, throughout the movement. In Examples 10-14, the motifs are underneath, as accompaniment or counterpoint, to the material that Taruskin likened to Vechnaya pamyat' (this happens many times, including at the beginning of the movement, shown in Example 10). Again, his calling this material "near citation" or "literal imitation" does not seem accurate, but in other instances where it (or one of its variations) occurs, the exact motifs, rhythms, and intoning timbre of Vechnaya pamyat' are right below them. The variations (see Example 11, highest voice, for example, and also Examples 32 and 33, discussed later) are also significant, in that they contain the repeated-note motif from the hymn. Perhaps this helps explain why this movement so strongly evoked the specific hymn Vechnaya pamyat' for Taruskin.

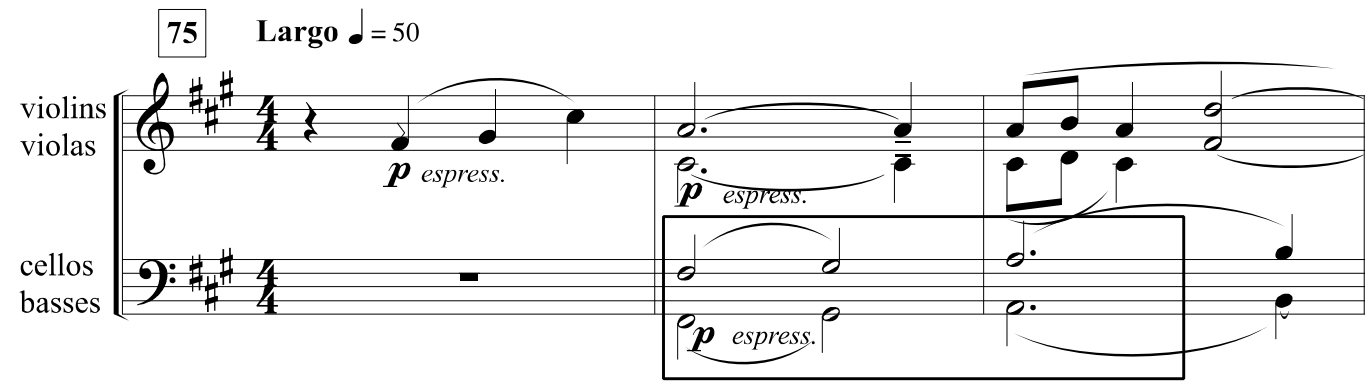

Example 10: Shostakovich, Symphony No. 5, Mvt. III, mm. 1-3.

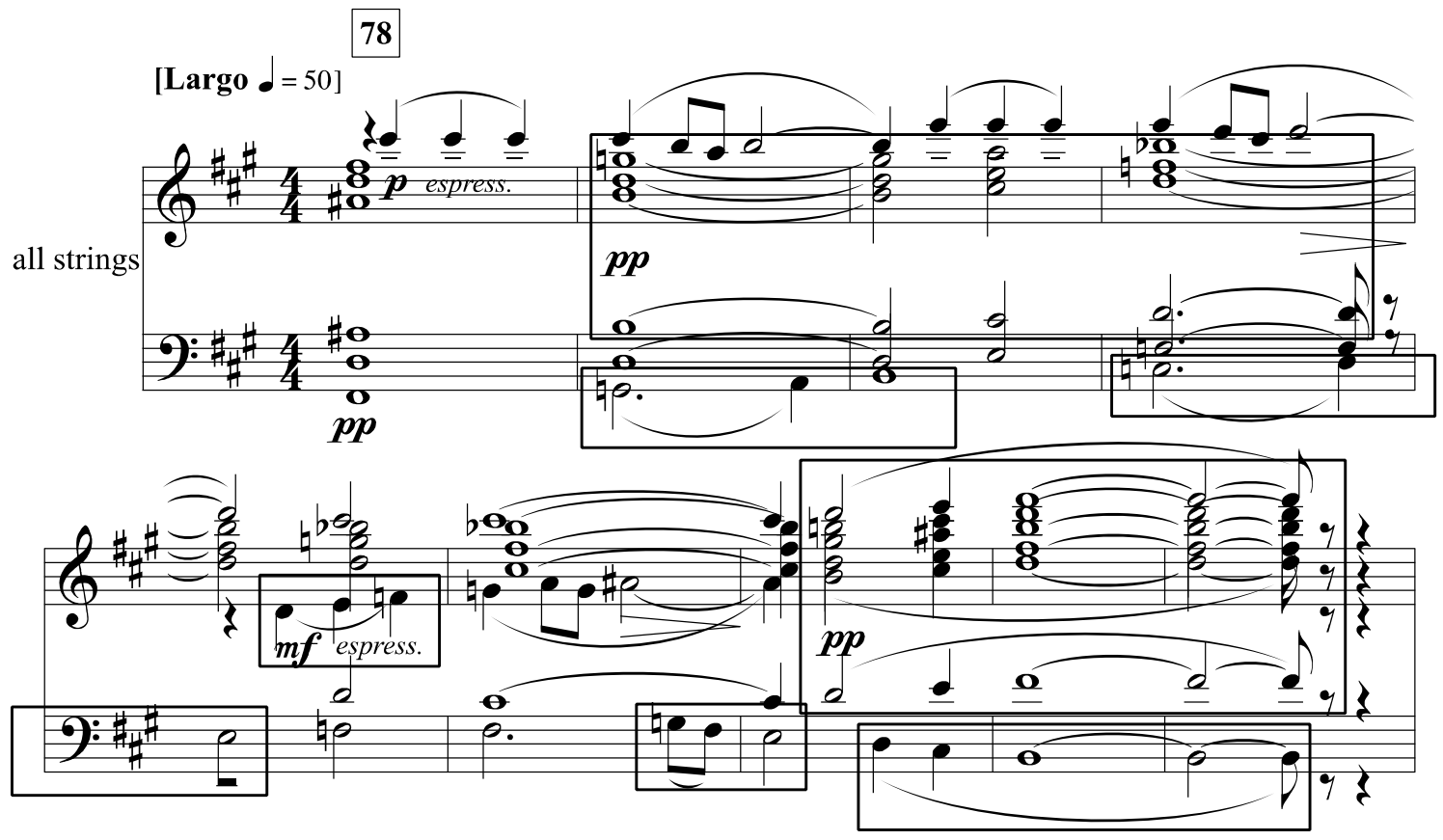

Example 11: Shostakovich, Symphony No. 5., Mvt. III, Rehearsal 78, all strings. 


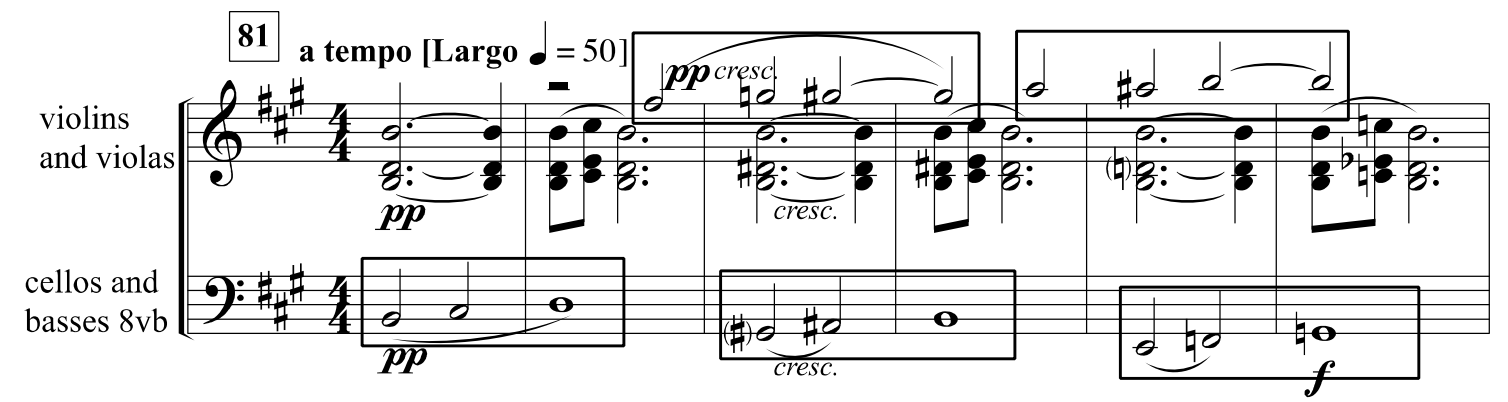

Example 12: Shostakovich, Symphony No. 5, Mvt. III, Rehearsal 81.

3 measures after

$85[$ Poco più mosso $d=72]$
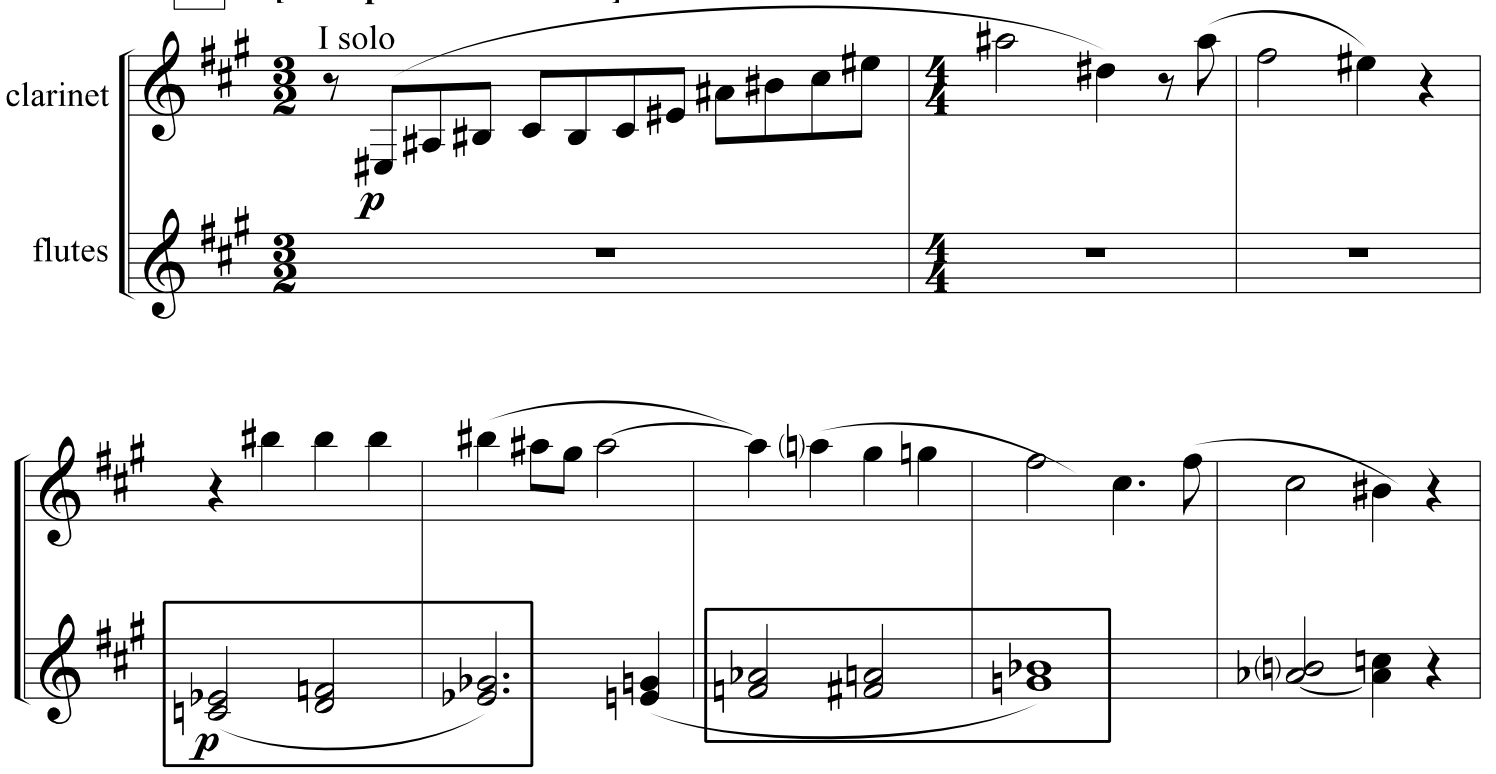

Example 13: Shostakovich, Symphony No. 5, Mvt III, measure 3 of Rehearsal 85, flutes and clarinets (strings omitted and including fully chromatic version of the motif).

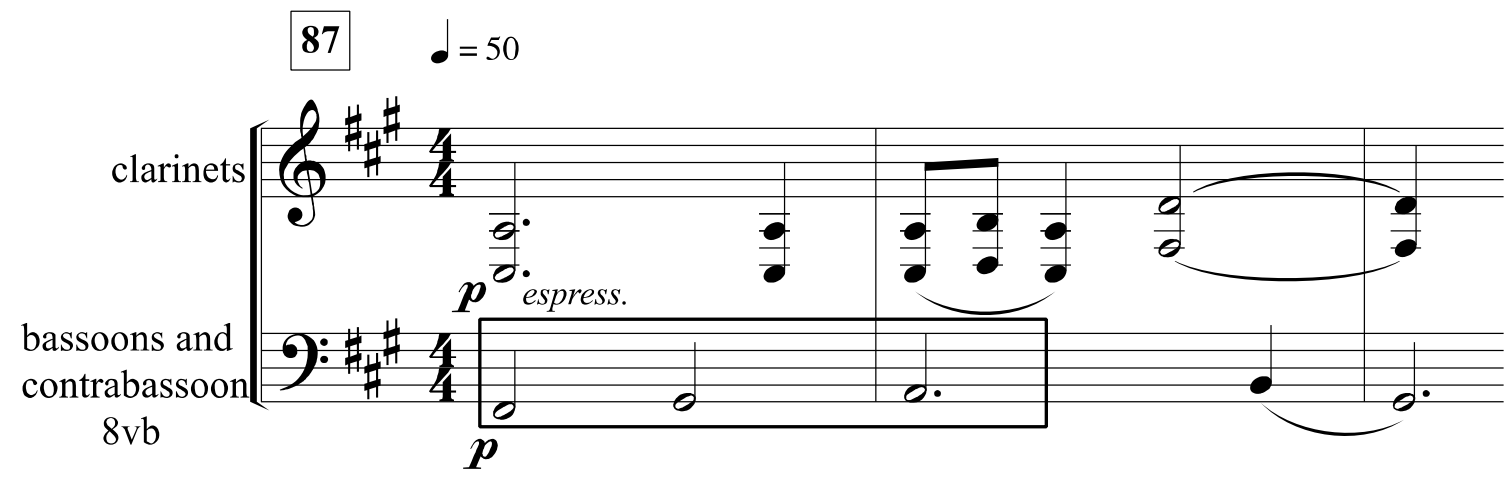

Example 14: Shostakovich, Symphony No. 5, Mvt. III, Rehearsal 87, clarinets and bassoons.

These instances of the three-note stepwise motif are quite audible and also noticeable by their repeated appearances. With a few exceptions, they are the whole step-half step, minor version as in the hymn-most especially at the beginnings of passages, such as in the examples above. The chromatically 


\section{Current Musicology}

altered versions of whole step-whole step (major), half step-half step (fully chromatic), and half step-whole step seem to occur in melodic sequences, with the alterations dictated by overall harmonic context-in other words, motivic development and transformation, explainable in "technical" terms, but also expressively interpretable. The motif (and its hypothesized reference to the funereal hymn) are prominent and recognizable, with brief turns to a brighter major-mode sound (perhaps for remembrance or consolation), and also to a tight, fully chromatic sound (perhaps for anguish or urgency). The half stepwhole step version, with its "phrygian" affect, of course stands out particularly, and will be discussed below.

The tense quality of the fully chromatic variant-having previously appeared, as in Examples 12 and 13-is later highlighted by rhythmic elongation, register, volume, and orchestration (see Example 15), and then, appears again in quiet, but very clear counterpoint with the minor and major versions of the motif (see Example 16).

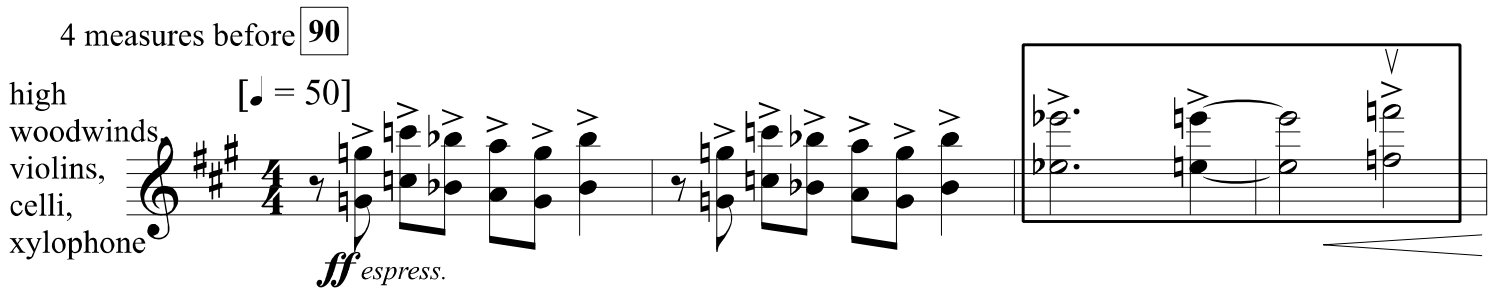

Example 15: Shostakovich, Symphony No. 5, Mvt. III, 4 measures before Rehearsal 90 (fully chromatic version).

The entire passage of Example 16, including its brief turn to the majormode version of the motif and a sinewy, slowly rising violin line, is eerily similar to the passage of Example 4-from the fourth movement. Taruskin makes the connection that the violin line there was a self-reference by Shostakovich to an accompaniment line from his own setting of Pushkin's poem Vozrozhdeniye ("Rebirth"), and he corrects what he says is a common mistranslation of the poem-the "rebirth" is not a promise of a bright future, but rather, an escape into the past. Taruskin furthermore cites Gerard McBurney's observation that the first four notes of the melody of this song match (exactly in pitch and very nearly in rhythm) with those of the fourth movement of the Fifth Symphony, including the anacrusis $(1997,532)$. See Example 17 for opening of the song; the referenced accompaniment line comes at the end of the song, not shown here. 
Eileen Mah

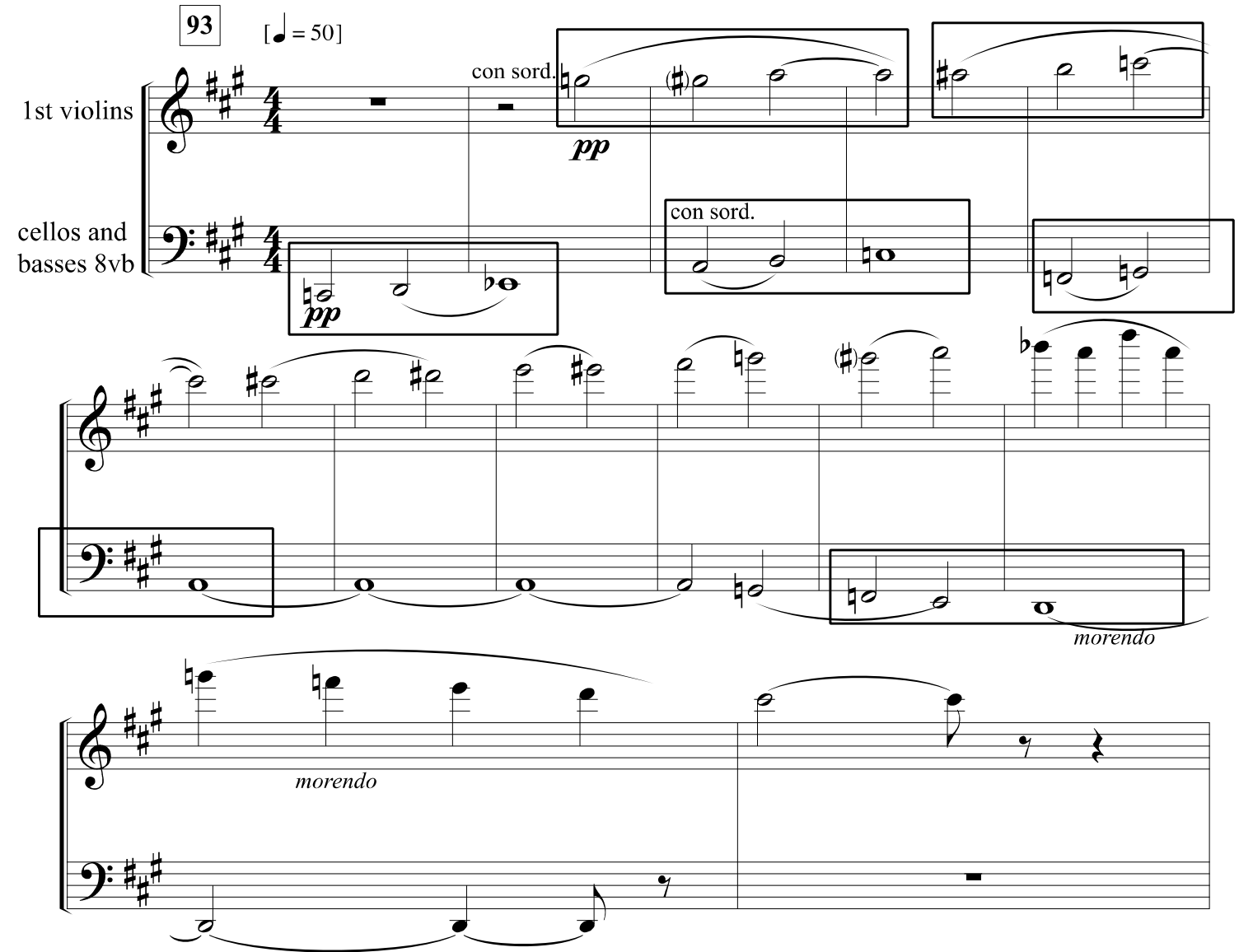

Example 16: Shostakovich, Symphony No. 5, Mvt. III, Rehearsal 93, first violins and cellos/basses (inner voices omitted and including fully chromatic version of the motif).
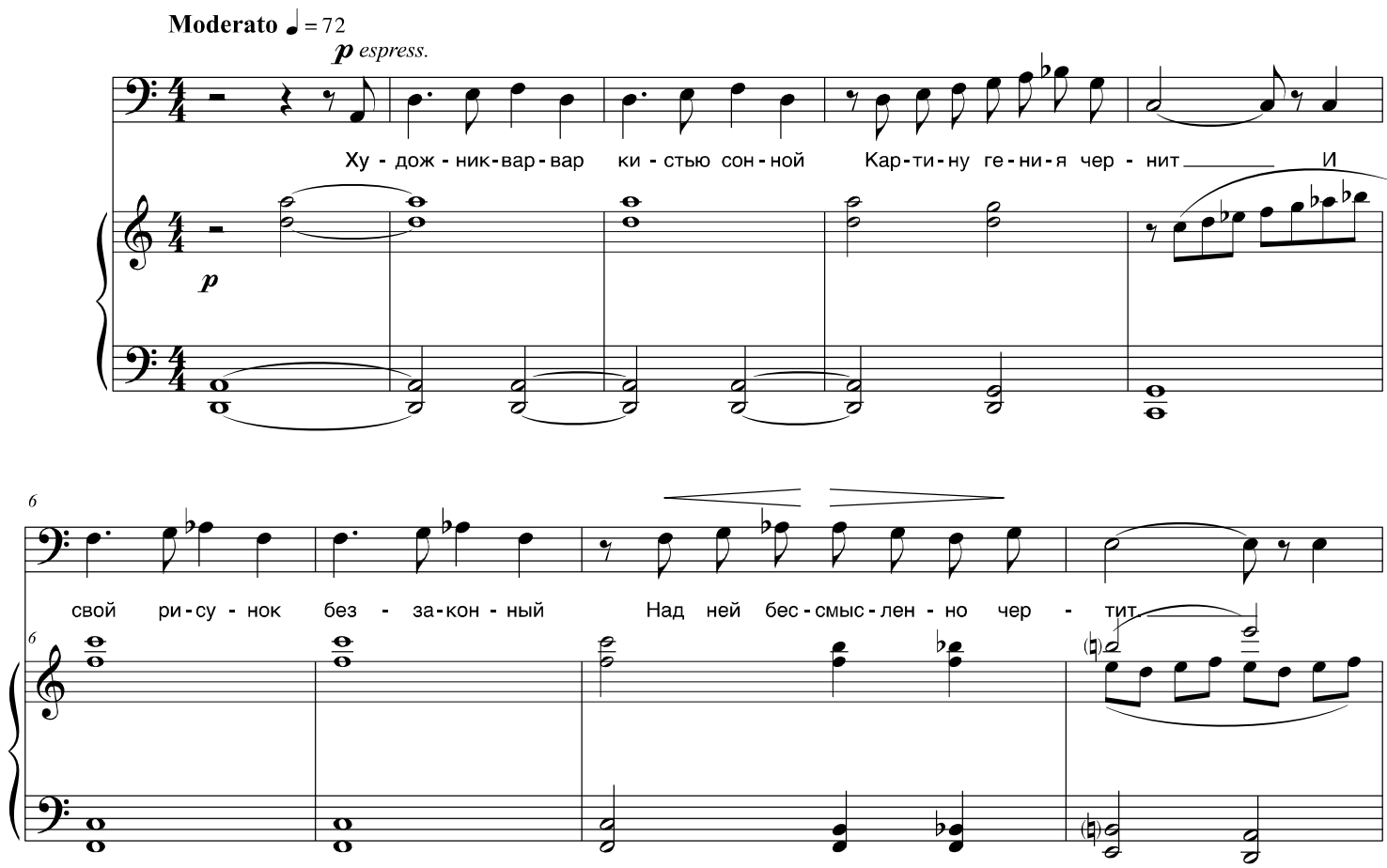

Example 17: Shostakovich, Vozrozhdeniye, mm. 1-9. 


\section{Current Musicology}

At this point, it would be valid to question how far these comparisons will go, and if they are just coincidences of commonly occurring notes and patterns (scale degrees 1,2, and 3), or just associations made by listeners, but with no provable authorial intentions. On the other hand, how does postulating about more meaningful, and even deliberate, correspondences fit into the discussion about truth, alternative facts, and the need for interpretation? Not to overquote Taruskin-especially since he does sometimes seem to contradict himself, and those contradictions are part of this current critique-but he does also ask and answer this question of "what in principle can validate or refute an interpretation of music [...]. That theory is better which better organizes the available information, or organizes more information [...] [and] should account for the introversive semiotic along with the extroversive" (1997, 539-40). Lack of "concrete" or "absolute" proof of authorial intention should never mean concluding that there was none, or that it is useless to investigate and analyze, or that it would be impossible to interpret commonly understood meanings from the sensual and ephemeral experience of individuals. Those are the alternative facts whose dissemination is most regrettable.

Plausible connections between Vozrozhdeniye and the Fifth Symphony can go farther, and can also include Vechnaya pamyat' and the half step-whole step "phrygian" variation of the three-note ascending motif. Shostakovich composed Vozrozhdeniye immediately prior to the symphony, and the passage from the fourth movement (Example 4) is truly quotational of the song, lending more validity to comparing the melodic motifs. The ending of the song, very much like the ending of the symphony, also introduces F-sharp to change the $\mathrm{D}$ minor opening to a D major conclusion, and also not without multiple reversions to flat notes along the way. The scale in the piano (right hand) (Example 17, $\mathrm{m}$. 5 ) is extremely similar to a theme from the symphony, first introduced one measure after reh. 5 in the first movement. Typically for Shostakovich, he also incorporates various striking chromatic alterations into both melody and harmony. For example, after transposing the opening motif D-E-F to F-G-A flat, Shostakovich alters the transposition so that the melody then lands on E-natural (with B-natural in the harmony), in measure 9 of the song (see Example 17). For me, knowing the symphony before the song, when I first heard this in the song, I immediately likened it to a melody from the end of the first movement of the symphony; upon examining the score, I found the exact same pitch collection in the first two measures of the melody, and then again in the third and fourth measures, transposed up (see Example 18). 
1 measure after

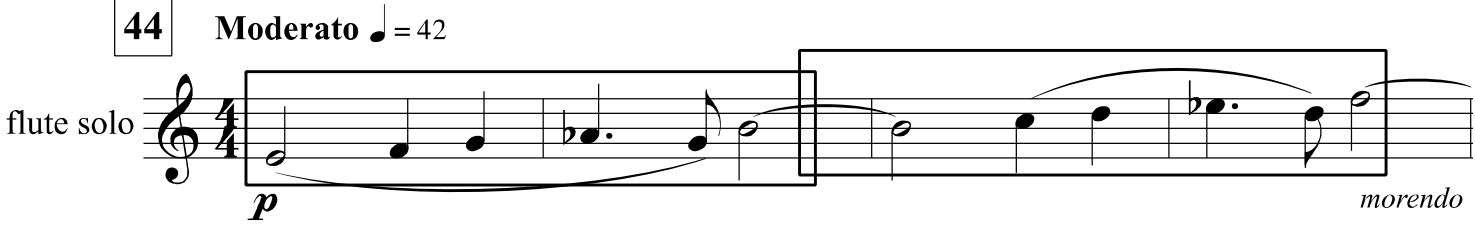

Example 18: Shostakovich, Symphony No. 5, Mvt. I, 1 measure after Rehearsal 44.

In the transposition of the melody (to B-C-D-E flat-F), the final note is lowered ( $\mathrm{F}$ instead of $\mathrm{F}$ sharp). This is now where I also make a connection to Vechnaya pamyat', which has these exact pitches (see Example 19). I was always struck by the B-natural in this melody, in the twice emphasized B natural-C-D on the final syllable of pamyat' (before settling on $\mathrm{C}$ at the end of the melody)the half step-whole step phrygian ascent is just as significant a motif as the whole step-half step ascent on vech-; it has a heightened expression because of its marked difference from either major or minor mode. In the Vechnaya melody, calling it phrygian-i.e., that the half step is between scale degrees 1 and 2 of the local motif, rather than between scale degrees 7 and 1 of the overall scale-is further justified by its marked presence in the elision of phrase ending and phrase beginning between iterations of the text.
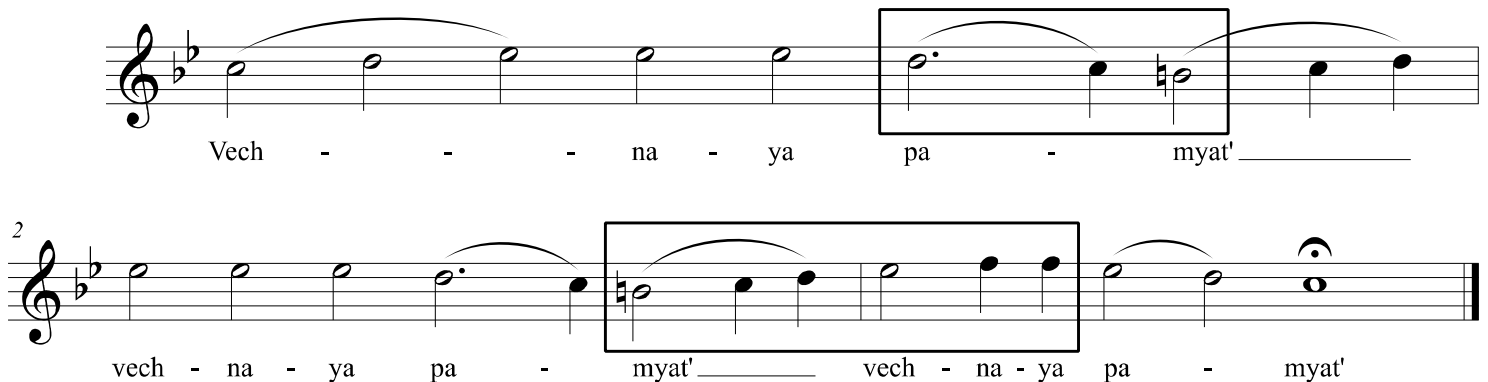

Example 19: Vechnaya pamyat', soprano (melody) part.

The melody at reh. 44 (in Example 18) is a sort of inversion of one of the main themes of the first movement (shown in Example 20), which is also varied in a different way later in the third movement (see Example 21). Both of these examples, then, do also contain the three-note stepwise motifs, though they are perhaps not audible in the same way as the ones in the earlier examples, since they are parts of longer melodies rather than isolated. They are still marked, however, by their lengthened rhythms and by their positions at both the beginnings and endings of phrases, just as in Vechnaya pamyat'. From here, it is easy to notice multiple other strikingly similar occurrences, throughout the first and second movements of the symphony, shown in Examples 22-25. 


\section{Current Musicology}
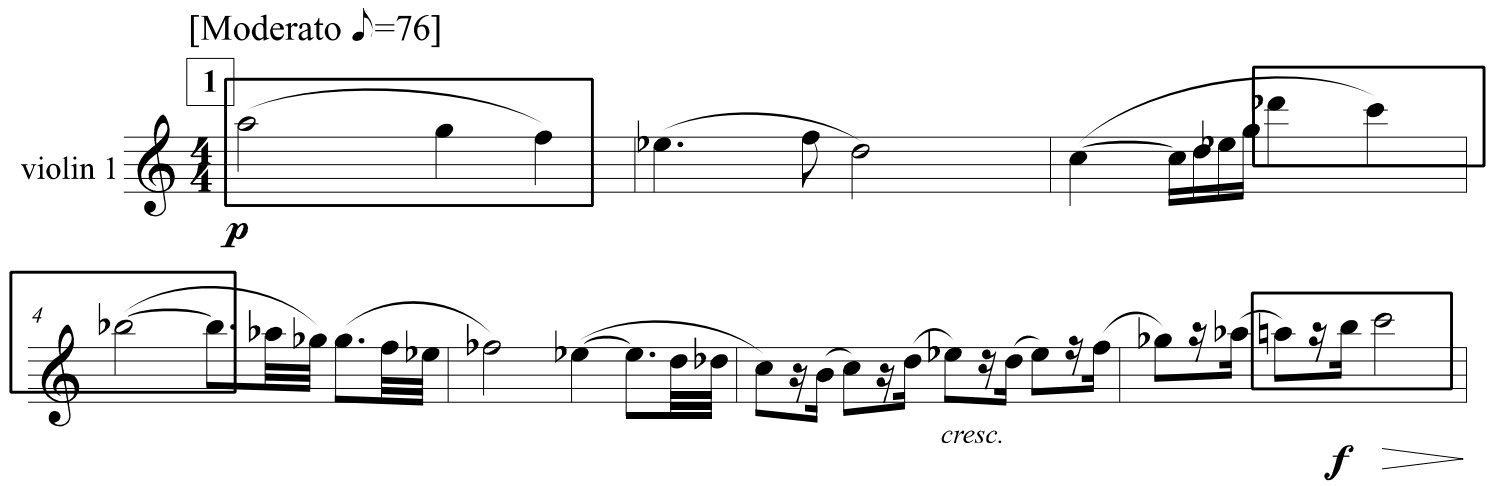

Example 20: Shostakovich, Symphony No. 5, Mvt. I, Rehearsal 1, first violins.

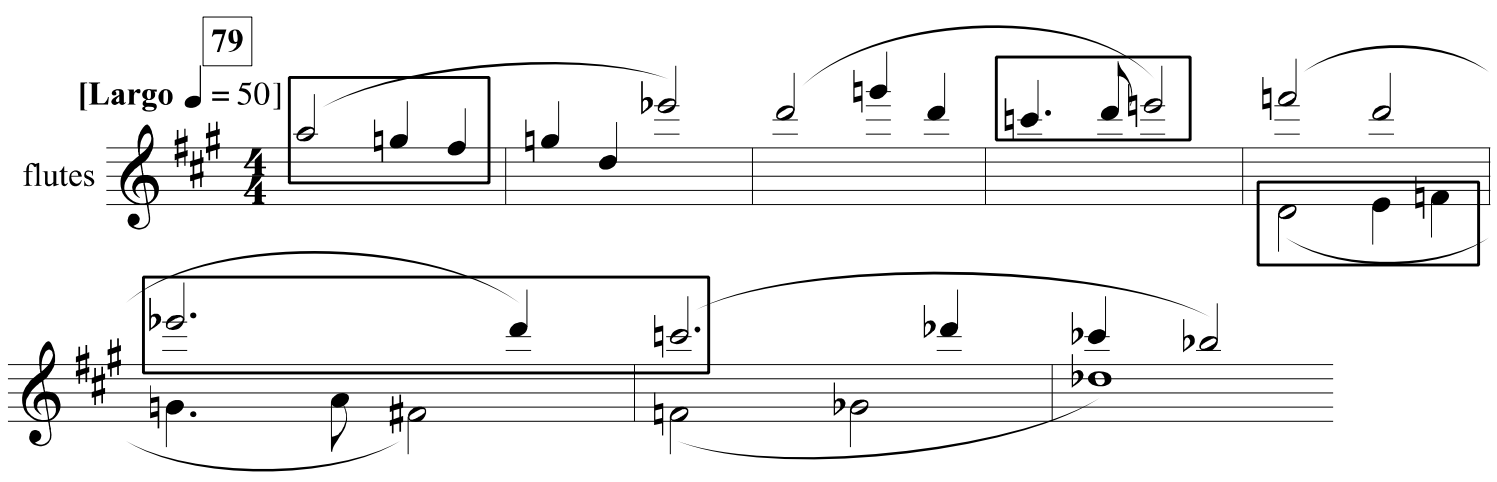

Example 21: Shostakovich, Symphony No. 5, Mvt. III, Rehearsal 79.

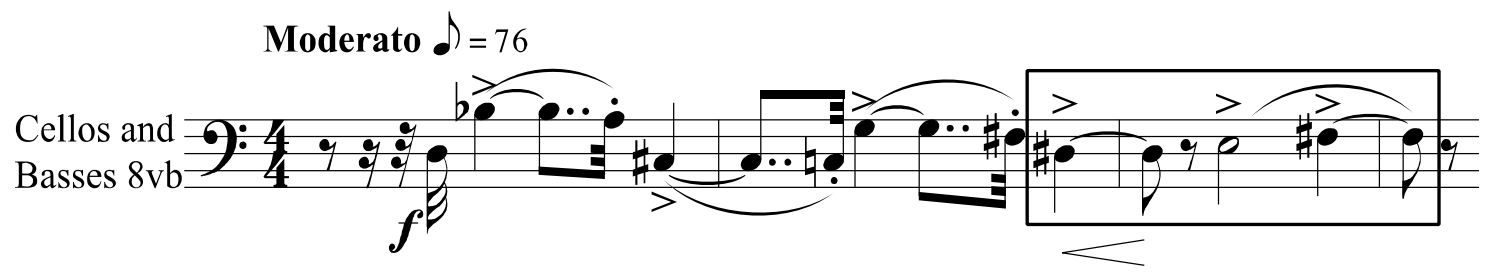

Example 22: Shostakovich, Symphony No. 5, Mvt. I, mm. 1-4. Half step-whole version of the motif. This is the beginning of the symphony and one of the main themes of the exposition.

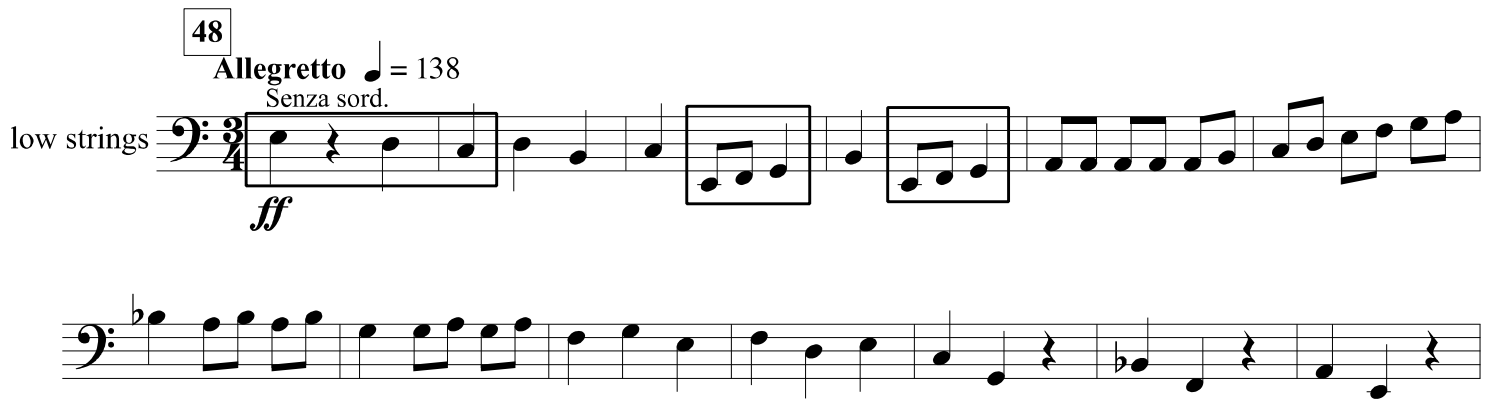

Example 23: Shostakovich, Symphony No. 5, Mvt. II, Rehearsal 48, low strings. 

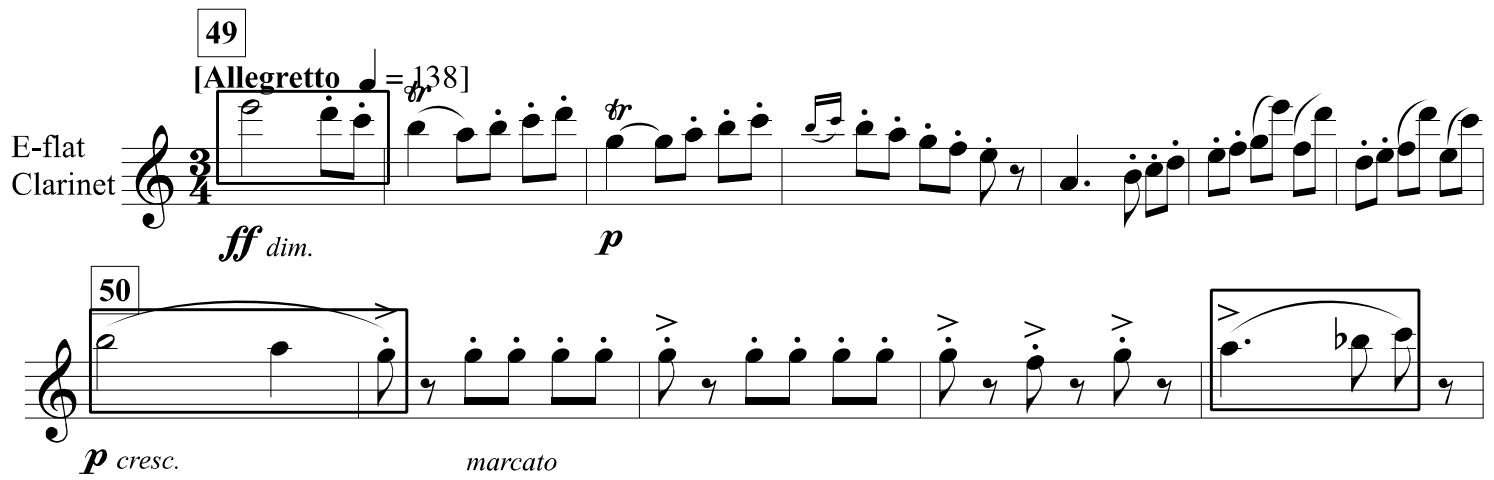

Example 24: Shostakovich, Symphony No. 5, Mvt. II, Rehearsal 49 (transposed to concert pitch).

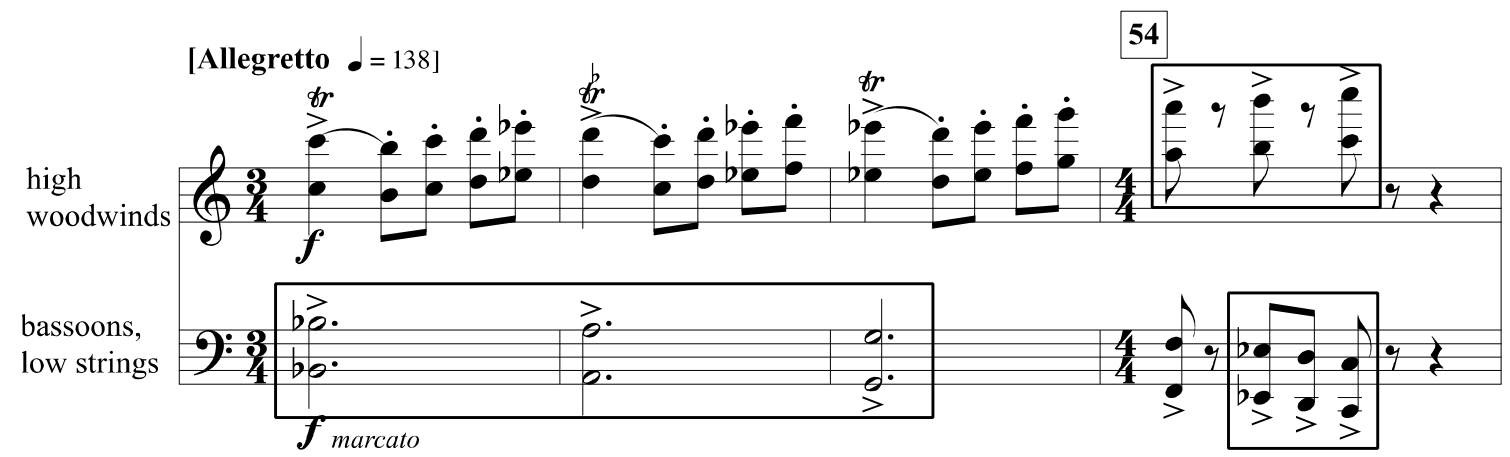

Example 25: Shostakovich, Symphony No. 5, Mvt. II, 3 measures before Rehearsal 54.

Now, in conjunction with these three-note ascending and descending motifs, and just as pervasive throughout the entire symphony, is the threerepeated-notes motif "B" (see Example 3), which assumes various rhythms, but, as with the stepwise motifs, eventually gets distilled and highlighted in its barest, long-note-value rhythm.

Motif "B" first appears in the rhythm of short-short-long, as in Example 26 , and many subsequent times. This first instance is also example of what Tilson Thomas calls the "dead end" usage of the repeated-note motif-in just the fourth measure of the entire piece, all the bold, driving vigor of the opening gesture (mm. 1-2) suddenly dissipates with the "retraction" of m. 3 , and then comes to a "dead end" with the repeated notes in m. 4 (2009).

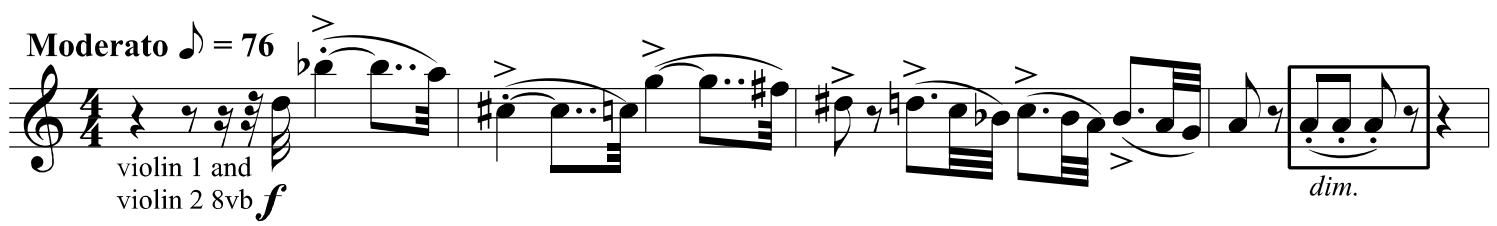

Example 26: Shostakovich, Symphony No. 5, Mvt. I, mm. 1-4.

The first rhythmic variation presents motif " $B$ " in the rhythm of longshort-short, and as a pulsing accompaniment, as in Example 27 and many 


\section{Current Musicology}

subsequent times, including the persistent ostinato in fast tempo of eighthsixteenth-sixteenth as at reh. 25 .

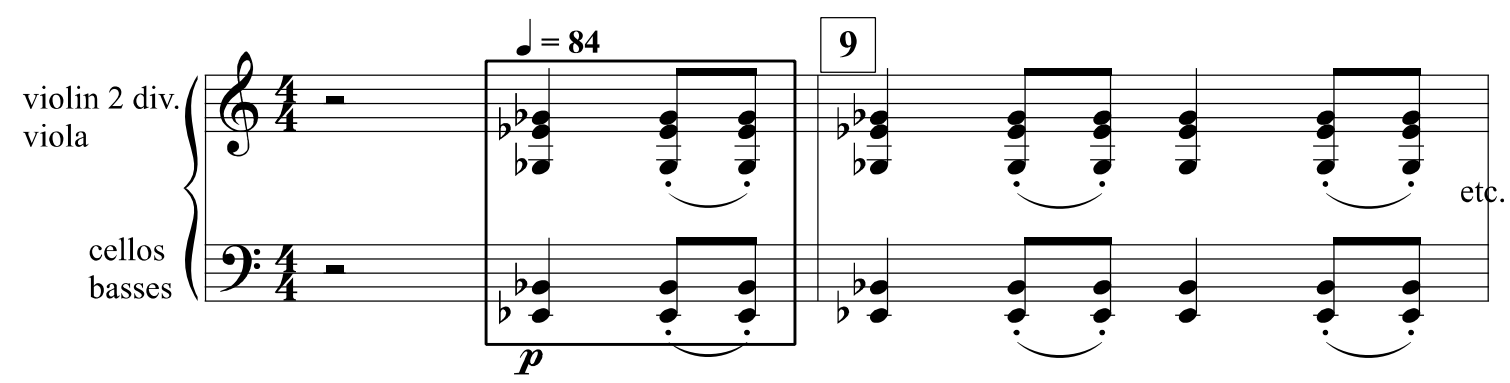

Example 27: Shostakovich, Symphony No. 5, Mvt. I, Rehearsal 9.

After the climactic full-orchestra unison between reh. 36 and 38, the repeated three notes return in another "dead end" or crisis moment, this time unavoidably low, slow, loud, accented, and repeated-“con tutta forza," so that the motif becomes something forceful and dominating, rather than accompanimental (see Example 28). Because of the number of repetitions, it becomes ambiguous as to whether the rhythm is short-short-long or long-shortshort, and this same material (only on the pitch $\mathrm{F}$, but again at fff volume) is also precisely what comes after the similar climax/crisis in the fourth movement, discussed above for Example 7 (see Example 29, which duplicates Example 7 and also shows the repeated-note motif that follows it). Just as the build-up to that crisis reminded me of Beethoven's Third, hearing this incessant pattern as longshort-short in both places reminds me of the second movement-also arguably funereal—of Beethoven's Seventh.

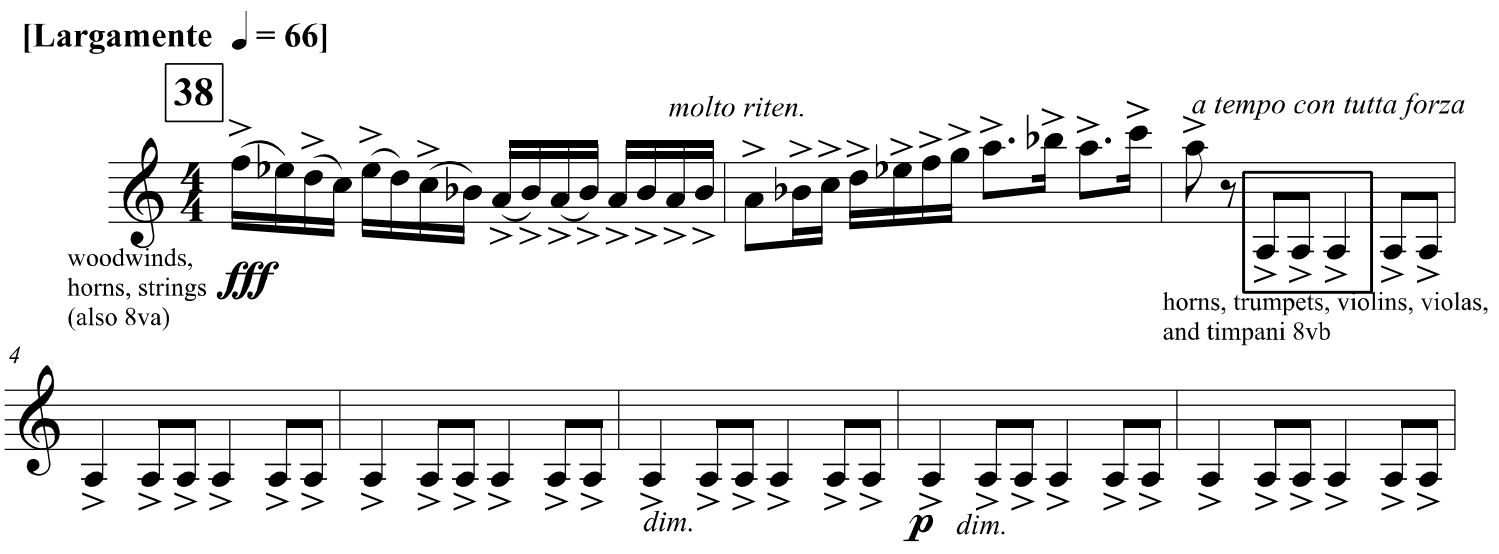

Example 28: Shostakovich, Symphony No. 5, Mvt. I, Rehearsal 38. 
1 measure after
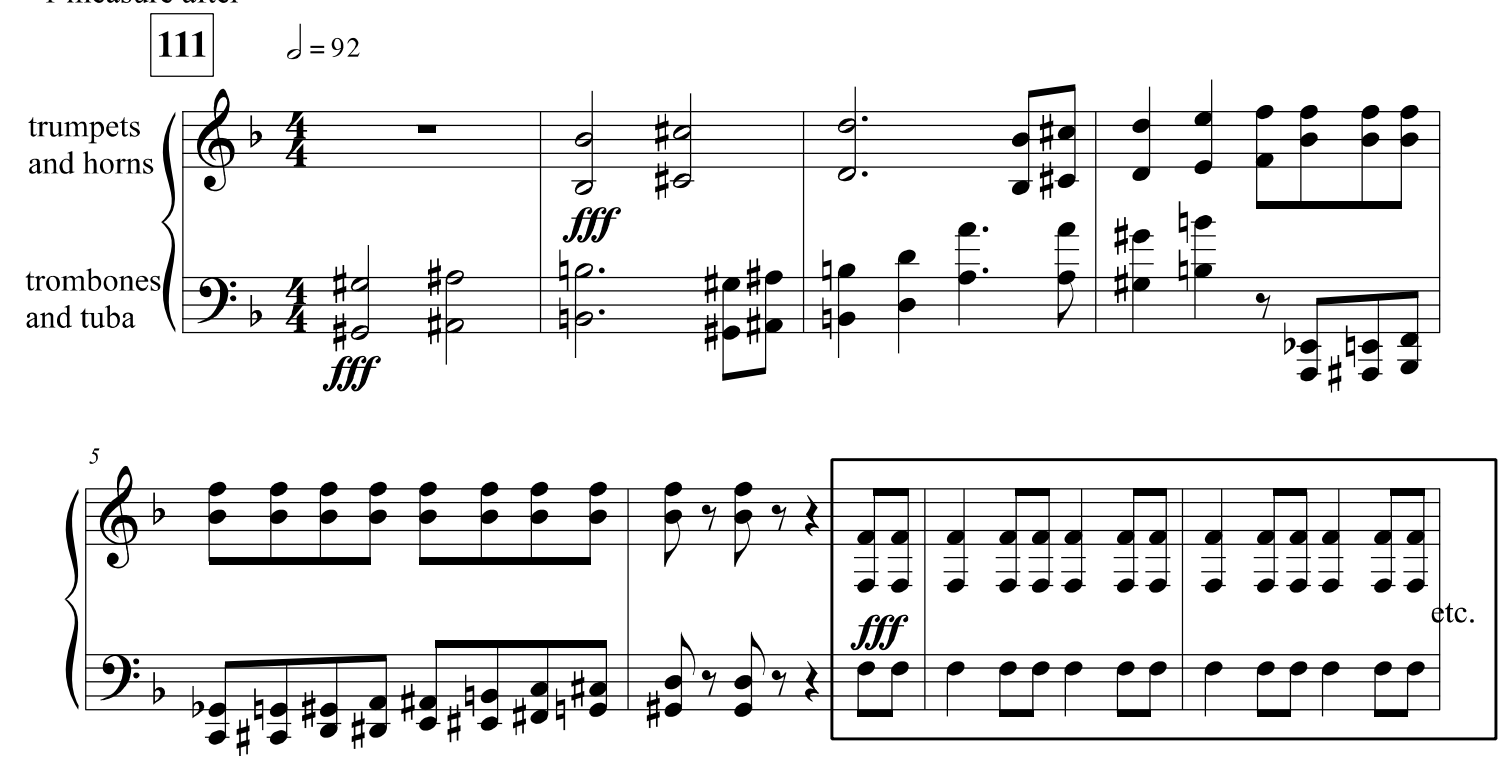

Example 29: Shostakovich, Symphony No. 5, Mvt. IV, 1 measure after Rehearsal 111.

Example 30 (and many subsequent repetitions) shows how this "B" motif is transformed into the melody of theme group 2 in the first movement, through combination of the short-short-long rhythm with a rearrangement of none other than the whole step-half step motif (motif "A").

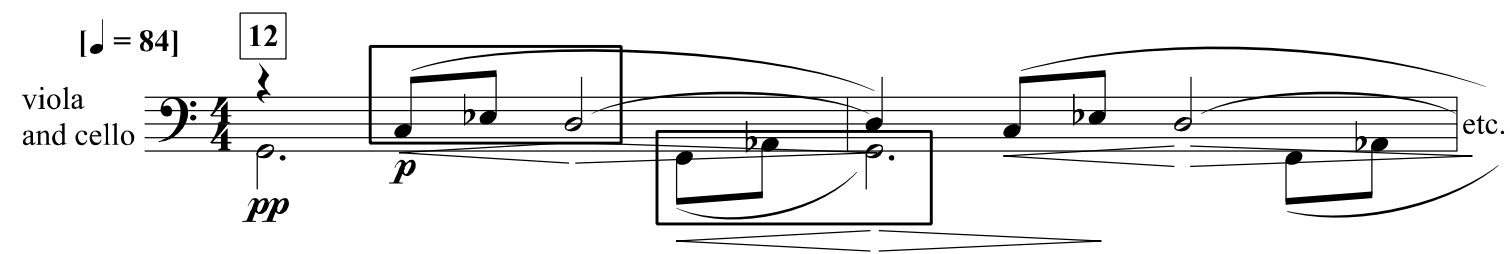

Example 30: Shostakovich, Symphony No. 5, Mvt. I, Rehearsal 12.

Motif " $\mathrm{B}$ " in its short-short-long arrangement also shows up as a persistent cell in the melody of the "trio" section of the second movement, shown in Example 31.

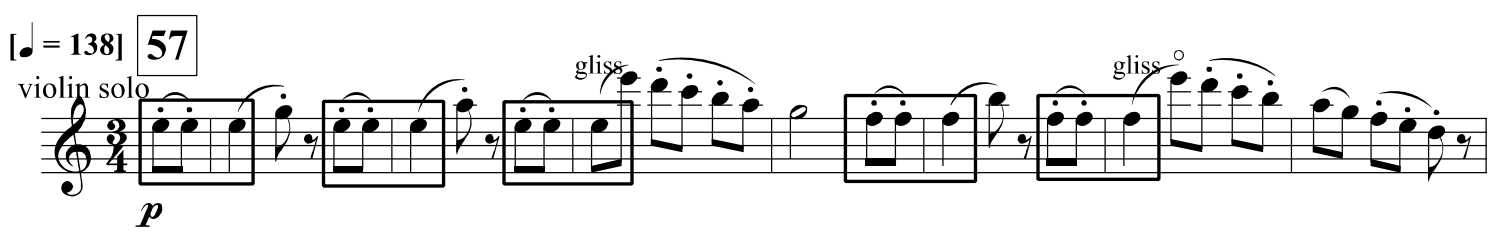

Example 31: Shostakovich, Symphony No. 5, Mvt. II, Rehearsal 57.

Just as happened to motif " $\mathrm{A}$ " through the course of the symphony, motif " $\mathrm{B}$ " also gradually becomes increasingly highlighted and increasingly distilled to its rhythm of long, equal note values, as in the hymn. In the third movement, the motif serves as essential cell in the chant-like melodies-the very ones that reminded Taruskin of Vechnaya pamyat' (see Examples 32 and 33). 


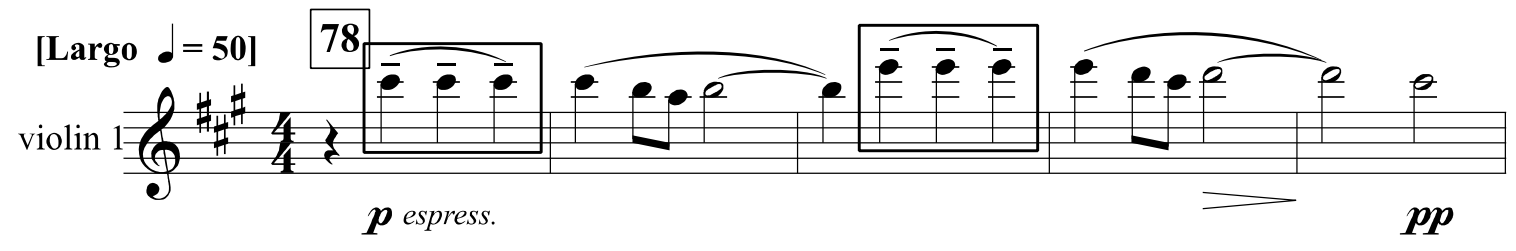

Example 32: Shostakovich, Symphony No. 5, Mvt. III, Rehearsal 78.

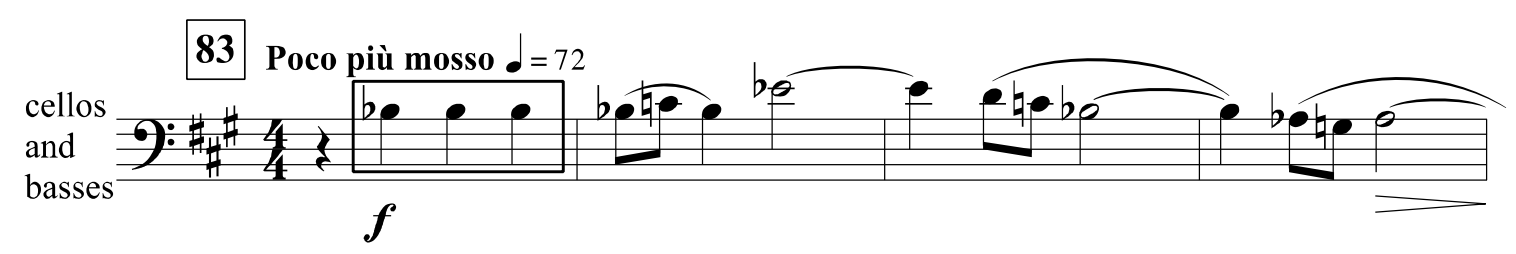

Example 33: Shostakovich, Symphony No. 5, Mvt. III, Rehearsal 83.

Example 34 shows another instance of the repeated note motif, combined with the chromatically ascending three-note motif, in another "crisis" or "dead end" moment.

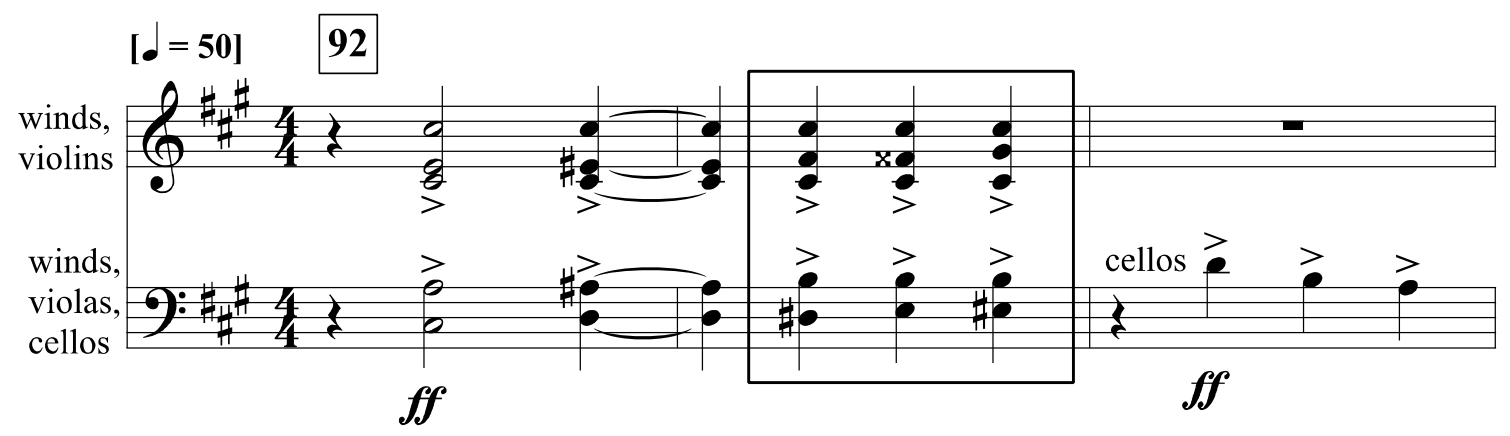

Example 34: Shostakovich, Symphony No. 5, Mvt. III, Rehearsal 92.

Finally, at the conclusion of the fourth movement, in the laborious build to $\mathrm{D}$ major from the slow, soft recapitulation of the main theme (recall the discussion preceding Example 8), motif "B" again appears, three times and in increasingly long note values (see Example 35) and then as the final gesture of the entire symphony in even longer values (see Example 36).

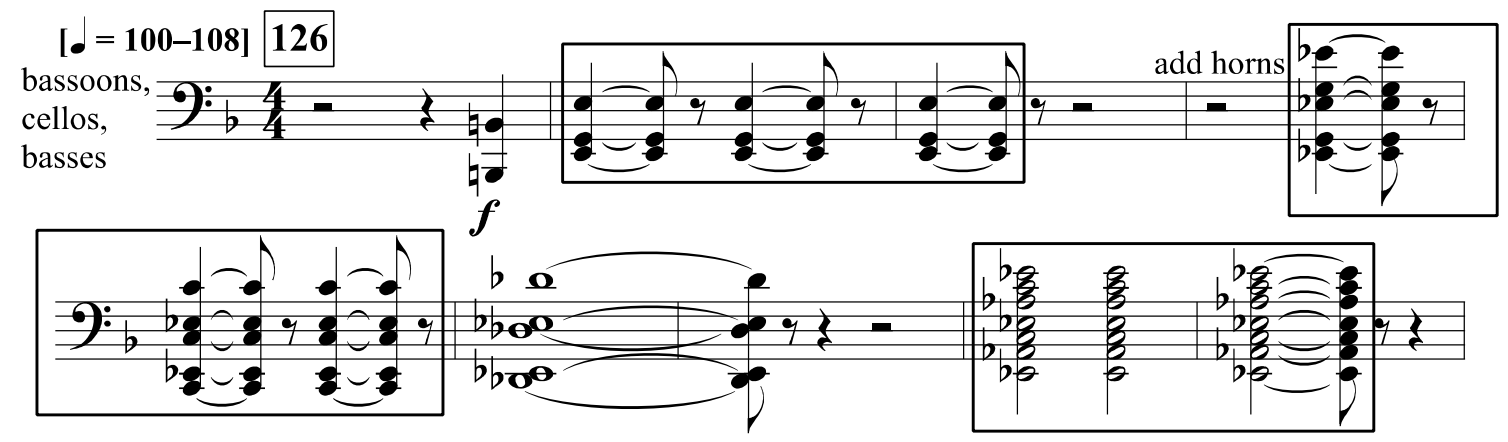

Example 35: Shostakovich, Symphony No. 5, Mvt. IV, Rehearsal 126. 


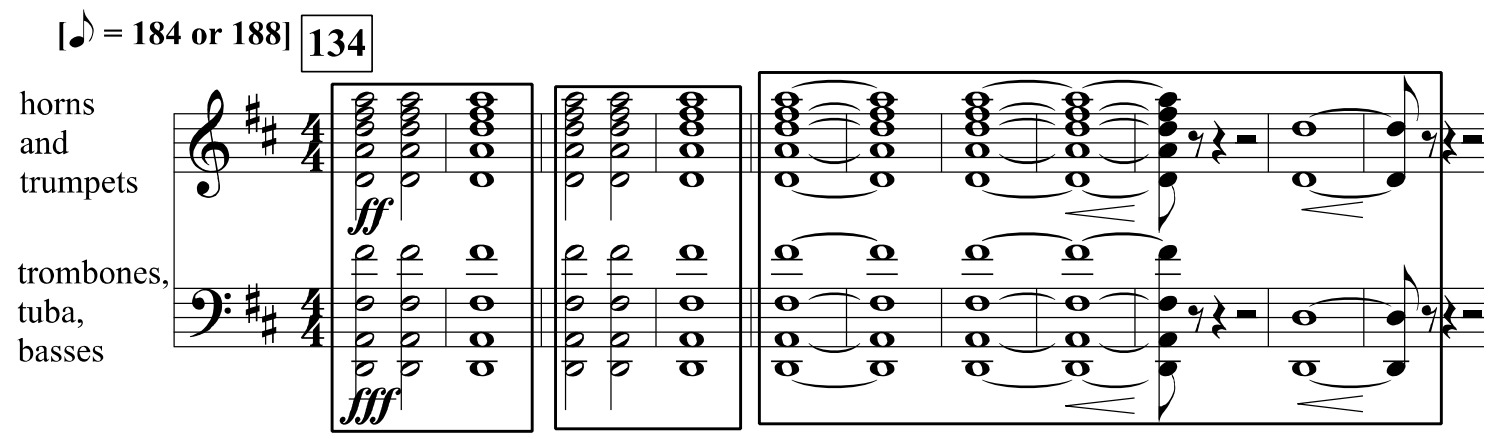

Example 36: Shostakovich, Symphony No. 5, Mvt. IV, Rehearsal 134.

To be clear, this current analysis in no way claims Vechnaya pamyat' to be a singular source or singular core of Shostakovich's Fifth. It is not even definitively "there" as a complete, quoted melody, and the symphony is replete with multiple other themes that are unique, memorable, and significant in their own rights. Analyzing all of them is beyond the scope and not the focus of this article. However, these many examples show the centrality of the motifs throughout the symphony, and their correlation to the other postulated source materials. In almost all cases, the motifs are clearly audible, if not unavoidably highlighted, unobstructed by other voices, and/or set apart by register (low or high), instrumental timbre, soli orchestration, articulation, or repetition.

Is this enough, though, to experience or interpret Vechnaya pamyat' as being present, other than the contextual reasons that would make this logical? The notes of the motifs are a common enough arrangement of common notesthey do also happen to be three simply repeated notes and scale degrees 1-2-3 or 7-1-2. One could also argue that liturgical chant melodies are often very similar to each other and generally are of limited range and melodic DNA, i.e., that a three-note scalar ascent or three repeated notes could be reminiscent of any number of chants. However, the melodies of those chants are not random, and furthermore, they are distinct, and distinguishable, and certain chants, such as Vechnaya, are more commonly performed and commonly recognizable, especially by their opening notes. Audibility and common recognition are at the heart of the functionality of musical topics and allusion in general; a large number of listeners will have immediate meaningful associations with the musical gesture, which includes any number of musical elements, not just pitch.

The exact matching of the motifs in the symphony to those of the hymn supports interpreting the collective (albeit fragmented) presence of the motifs as a recognizable quotation from the hymn. Further persuasion comes from their rhythmic presentation, the range and the timbre, the presence and combination of both the stepwise motifs and the repeated-note motif, the context of the third 


\section{Current Musicology}

movement as a whole in the many ways that it evokes grief and the ritual of the Russian Orthodox requiem, and finally, precisely the simplicity of the motifs, which, along with their prominence and pervasiveness, marks them for interpretation. Having the simplicity of the motifs be explainable as Beethovenian, or as Fanning put it, working "reciprocally with the complex longterm structural processes" $(2001,139)$, would be a perfect safety net for being able to deny the presence of specifically identifiable referential material problematic to the regime, since Shostakovich does seem to be referring to the Orthodox service in, at very least, a general way. ${ }^{4}$ Meanwhile, motifs from the recognizable Vechnaya pamyat' pervade the entire symphony, and much more directly than Taruskin analyzed, with incredible relevance and poignance in the hymn never being fully uttered-the fragmented and therefore intensified pain of suppressed loss and grief. Vechnaya pamyat'-"Memory Eternal"-has a double irony: first, being forced to forget (because of the silencing of grief, or even the alternative fact that no one died and nothing happened), but at the same time, despite being forced to forget, the impossibility of actually forgetting. This resonates with Taruskin's spot-on observation about the ironic silencing of the brass section in the third movement $(1997,530)$.

In Taruskin's disavowal of the term "dissident" (1997, $535 \mathrm{ff}$.), he insists that Shostakovich's overall message in the Fifth is one of irony rather than mockery $(1997,540)$. However, while Shostakovich may not technically have been a dissident as understood in later contexts, Taruskin has interpreted the Fifth Symphony as a very real portrayal of suffering in the specific context of Stalinist Russia, and the ironies of still managing to remain alive and even a favored composer at various times. Vechnaya pamyat' was a well-known memorial for the dead, and if everyone knew the reason for their deaths, then this memorial itself was not even ironic. The irony is perhaps in expressing this grief in a banned form, inside a symphony that would officially rehabilitate Shostakovich. In so far as dissidence could be expressed in Stalinist Russia, this is it. Taruskin calls it Shostakovich's "doubleness" $(2009,304)$-and that is a fine term. If, through doubleness, Shostakovich was able to reflect life as it really was despite the condition of living in a world of alternative facts, this would be an act of resistance in itself.

As with the requiem reference in Tchaikovsky's Sixth, the pervasive presence of the requiem hymn in Shostakovich's symphony would beg the question of who or what is being mourned. In this case, the idea of requiem is of course logical in conjunction with the literal deaths and other losses at the hands of Stalin's regime, but also with the other suggested allusions and quotations 
from Vozrozhdeniye - in the context of destruction, terror, and fear, a longing for rebirth by returning to a remembered past. Additionally, Elizabeth Wilson surveys at least two authors' theories on allusions to Bizet's Carmen, along with a suggested program of Shostakovich's own love life and rejection by Elena Konstantinovskaya, who later went to Spain and married one Roman Karmen. Without diverging into discussion of those "Carmen" motifs and that program, we can note that lost love is also compatible with the idea of requiem, and I cannot help but notice that in one author's description of the love program, he uses the word "hymn" to describe the entire Fifth Symphony (Wilson 2006, 15354). The Russian violinist Zoya Leybin of the San Francisco Symphony also uses the word hymn in the concluding, summarizing moments of Michael Tilson Thomas's film (2009); in both cases, these commentators were not speaking of a specific hymn reference, or even of the hymnic third movement, but notably, they both had a feeling of hymn pervading the entire work.

The motifs identified in this paper can also be multivalent without canceling each other. The repeated-note motif could be a quotation from Vechnaya pamyat', or it could be a feeling of dead-end and being beaten into submission (Tilson Thomas 2009), or it could be a reference to Beethoven's funereal music, or it could be a simple accompanimental rhythm, or it could be all of these things. The stepwise motifs could be quotations from Vechnaya pamyat', or from Vozrozhdeniye, or they could be notes chosen from scalar patterns, or they could be all of those things.

Forming a picture of the whole is complicated, especially when it may be made from fragments, or when, as David Fanning puts it, the surface of the music is "overlaid with mirrors... [and] we can never be precisely sure where and at what angle they are placed" $(2004,6)$. Taruskin expresses this idea similarly: "It is never just Shostakovich. It is always Shostakovich and us" (1997, 476-77). Complicating though this may be, the presence of complication or contradiction does not mean we should just throw our hands in the air; any hope of sorting it out requires seeking and identifying and naming exactly what those complicating or contradictory elements are, and making the effort to identify true from false. Regardless of which program(s) Shostakovich may have had in mind or which program(s) anyone chooses to assign, the pervasive sorrow of the requiem hymn - all the way to the very last notes of the symphony - would be a specific piece of evidence (among many others) ${ }^{5}$ in the total estimation, at the end of the symphony, that, as Tilson Thomas put very well, "the happy harmonies of the ending are utterly false"-or, if you will, an alternative fact 


\section{Current Musicology}

(2009). This could be an alternative fact that Shostakovich is portraying, or one that he himself is manipulating, or both.

Returning to the ideas of interpretational hesitancy both inside and outside academia: Many analyses aimed at the general public or students do well with play-by-play recounting of the "purely musical" processes. The conventions of programs notes-among them to lend themselves to quick reading for audience members experiencing a piece of music for the first time, in real timemight explain (though not necessarily excuse) Philip Huscher's already mentioned program notes for the Chicago Symphony. Another example, then, of analysis aimed at a similar audience, but one listening to and studying the music in a more asynchronous vein, is Gerard Schwarz's four-part video analysis (with the Seattle Symphony) posted on the much-used education site Khan Academy. Though lengthier and more detailed than any typical program note, Schwarz's analysis still offers mostly play-by-play recounting, with only vaguely interpretive descriptors such as poignant, powerful, climactic, and aggressive (2012). By contrast, Tilson Thomas (2009), while clearly aware of the "Shostakovich Wars," and perhaps also aware of Taruskin's contemporaneous digs at "baton wavers" $(2009,23)$, offers vastly more specific and thorough descriptors, and importantly, quite specific interpretations. Does this debase the musical discourse? No-again, multiplicity of interpretation does not preclude specificity of interpretation. Does a specific interpretation lock the music in the past? No-a claim such as that subscribes to the idea that history is only about the past; more than this, history is about the relationship of the past to the present and the future.

In his writings on Shostakovich, Taruskin consistently casts doubt on viewing musical meaning as "vested in it by the creator" $(2009,310)$, butperhaps in self-contradiction-he also consistently argues that Shostakovich "insisted on keeping the latent content latent, and keeping it labile [...] As long as music is left to 'speak for itself,' it can speak only truth" (1997, 483). Taruskin acknowledges the contradictions and ambiguities in Shostakovich's music, but also repeatedly argues that it is "better to let the contradictions stand" (2009, 318), rather than trying to "resolve" or "eliminate" them, as this will result in falsehoods/lies $(1997,483)$, and in "reduction not only of meaning but in interest and value" $(1997,476)$. Even if overly literal or overly biographical readings are to be avoided, this does not mean we should stop analyzing, reasoning that "we can never really know anything for sure." On the contrary, if there are contradictions and ambiguities, it is vitally important to say exactly what they are, and grapple with interpreting them, in specific ways. If there are multiple 
interpretations, rather than despair over the futility of "endless interpretations," it is rather the job of the interpreter to ask and answer why it meant one thing to these people but another thing to those people.

Furthermore, alternative facts are part and parcel of totalitarian regimes, and usually not based on any logical evidence or reasoning whatsoever, as the ulterior motive is more the point. The significance of Stalinist officials' interpretations of Shostakovich's Fifth, then, is less about why they interpreted it that way and more about the fact that they had the power to interpret it in any way they chose; they could condemn or embrace Shostakovich, regardless of how they claimed to understand his music-and many Stalinist officials may well have had their own private understandings, which they would, of course, never make public.

The alternative fact can be understood as a set of contradictions and ambiguities, and a piece of music may contain alternative facts, vested in it by composer, listener, listeners influencing each other over time, and/or arguing musicologists. The nature of truth or meaning in works of art is not necessarily the same as in other spheres-say, politics, science, or sociology. However, musical "data" (such as the motifs identified in this paper) may not be that different from any other data, in that different people can analyze it in different ways, use it in different ways, twist it in different ways, contextualize it in different ways, or isolate it from its context. In music, just as in other fields, the social and political connections are very real and do have high stakes-including the very definitions of music, types of music, music making, and musical meaning.

Moreover, our cultural habits are important. How we operate within academia is both influential on and influenced by the larger cultural context, and musicology cannot claim itself immune to alternative facts and logical fallacies, or exempt from interpretation, especially when these ideas are present in scholarship at the highest levels. As in politics, musicological alternative facts subsequently have a powerful potential in their dissemination to all types of media and all levels of listeners, from serious researchers to audiences who may not question alternative facts or who may continue to spread them-students, the internet- or newspaper-reading public, casual concert goers perusing program notes, consumers of musical recordings reading liner notes, or teachers looking for prepackaged "expert opinions" to form attractive course materials. Finally, there are the listeners from the time and place of any piece of music. In the case of Shostakovich's Fifth, these are listeners who perhaps lived the truths reflected in his music, but who could not question alternative facts, even if they 


\section{Current Musicology}

knew them to be false. We should at least try to be empathetic listeners, and we may discover some truths about our own time and place.

\section{Copyright Acknowledgement}

All score samples are provided courtesy of G. Schirmer, Inc.

SYMPHONY NO. 5 IN D MINOR, OP. 47

By Dmitri Shostakovich

Copyright ( 1939 by G. Schirmer, Inc. (ASCAP)

International Copyright Secured. All Rights Reserved.

Used by Permission.

Notes

${ }^{1}$ One example: "Keeping Score: Keeping Score | Dmitri Shostakovich: Symphony No. 5 (FULL DOCUMENTARY AND CONCERT)," https://www.youtube.com/watch?v=e3RbWSfhlp4. More discussion of this particular video toward the end of this paper.

${ }^{2}$ For more on implicit but pervasive imprints of Russian Orthodox liturgy in Shostakovich's music, see Alexander Ivashkin, "Shostakovich, Old Believers and New Minimalists," in Contemplating Shostakovich: Life, Music and Film, eds. Alexander Ivashkin and Andrew Kirkman (Surrey: Ashgate, 2012), 42-43.

${ }^{3}$ This 1869 edition by Bakhmetev was adopted as standard and for the most part retained even after Balakirev and Rimsky-Korsakov made subsequent harmonizations in the 1880s; in any case, regardless of which edition Shostakovich might have known, the chant melody is what pertains to this discussion. For more on these editions of the obikhod, see Carolyn C. Dunlop, Russian Court Chapel Choir: 1796-1917 (New York, NY: Routledge, 2013), 76-79, or Suzel Ana Reily and Jonathan M. Dueck, eds., The Oxford Handbook of Music and World Christianities (Oxford: Oxford University Press, 2016), 367-74.

${ }^{4}$ Esti Sheinberg also discusses at length Shostakovich's "multi-layered musical discourse," including his juxtaposition of "exaggerated musical simplicity" with its "normal" surrounding material in order to express irony or satire. See Esti Sheinberg, Irony, Satire, Parody and the Grotesque in the Music of Shostakovich: A Theory of Musical Incongruities (Aldershot: Ashgate, 200), $46 \mathrm{ff}$ and $62 \mathrm{ff}$, among others.

${ }^{5}$ These include: the too-slow tempo, the dissonance and struggle leading up to the ending, the absurd repetition of the high $\mathrm{A}$ in the violins, the modal mixture of B-flat and C-natural into the $\mathrm{D}$ major key, the bare $\mathrm{D}$ (without any other chord tones) on the very final sonority.

\section{References}

Abbate, Carolyn. 2004. “Music-Drastic or Gnostic?” Critical Inquiry 30: 505-36. 2017. “Overlooking the Ephemeral.” New Literary History 48: 75-102.

Bellman, Jonathan D. 2017. "After Silence, That Which Comes Nearest.” In Ineffability: An Exercise in Comparative Philosophy of Religion, Comparative Philosophy of Religion I, 
edited by T.D. Knepper and L.E. Kalmanson, 41-58. Cham, Switzerland: Springer International Publishing.

Berger, Karol. 2005. "Musicology According to Don Giovanni, or: Should We Get Drastic?"

The Journal of Musicology 22/3: 490-501.

Davis, Anna Megan. 2011. A Russian Eschatology: Theological Reflections on the Music of

Dmitri Shostakovich. Ph.D. Thesis, University of Exeter.

Fairclough, Pauline. 2019. Dmitry Shostakovich. London: Reaktion Books. . 2001. "Mahler Reconstructed: Sollertinsky and the Soviet Symphony." Musical Quarterly 85/2: 367-90.

Fanning, David. 2001. “Shostakovich: 'Present-Day Master of the C Major Key'.” Acta Musicologica 73/2: 101-40. . 2004. Shostakovich: String Quartet No. 8. Aldershot: Ashgate.

Gumbrecht, Hans Ulrich. 2004. Production of Presence: What Meaning Cannot Convey. Stanford: Stanford University Press.

Horton, Julian. 2020. "On the Musicological Necessity of Musical Analysis.” The Musical Quarterly 103/1-2: 62-104.

Huscher, Phillip. 2017. Programs notes, Chicago Symphony Orchestra, 21-23 December 2017.

Jackson, Timothy L. 1999. Tchaikovsky: Symphony No. 6 (Pathétique). Cambridge: Cambridge University Press.

Keller, James M. 2019. Program notes, New York Philharmonic, 6-9 March 2019. https://nyphil.org/ /media/pdfs/program-notes/1819/Tchaikovsky-Symphony-No-6.pdf.

Lihoreau, Tim. 2018. Case Notes: Episode 5: The mystery of Tchaikovsky's death. Classicfm blog talk radio. https://www.blogtalkradio.com/dax-global-classicfmcasenotes/2018/05/03/episode-5-the-mystery-of-tchaikovskys-death

May, Thomas. “Symphony No. 6, 'Pathétique'.” Program notes, Los Angeles Philharmonic, 30 November-2 December 2018. https://www.laphil.com/musicdb/pieces/4036/symphony-no-6-pathetique.

Orlova, Aleksandra. 1980. "Tayna smerti Chaykovskogo” [The secret of Tchaikovsky's death]. Novïy Amerikanets, 40: 22-3. . 1981. "Tchaikovsky: The Last Chapter." Music \& Letters, 62: 125-45.

Schwarz, Gerard. 2012. Dmitri Shostakovich: Symphony No. 5. Analysis by Gerard Schwarz. Video made with The All-Star Orchestra in partnership with Khan Academy (filmed in 2012, originally aired 2014), available at https://www.khanacademy.org/humanities/music/music- masterpieces-oldnew\#shostakovich5thagain.

Sontag, Susan. 1966. Against Interpretation and Other Essays. New York: Farrar, Straus \& Giroux.

Taruskin, Richard. 1995. "Public Lies and Unspeakable Truth: Interpreting Shostakovich's Fifth Symphony." In Shostakovich Studies, edited by David Fanning, 17-56. Cambridge: Cambridge University Press. . 1997. Defining Russia Musically: Historical and Hermeneutical Essays.

Princeton: Princeton University Press. 2009. On Russian Music. Berkeley: University of California Press. 
Tilson Thomas, Michael. 2009. Keeping Score: Shostakovich: Symphony No. 5. DVD created by Michael Tilson Thomas with the San Francisco Symphony; also available online at https://www.youtube.com/watch?v=e3RbWSfhlp.

Wiley, Roland John. “Tchaikovsky, Pyotr Il'yich.” In Grove Music Online, Oxford Music Online. Oxford University Press, accessed 30 July 2020.

Wilson, Elizabeth. 2006. Shostakovich: A Life Remembered, Second Edition. London: Faber and Faber. 